\title{
Cheap Speech and What It Will Do
}

\author{
Eugene Volokh ${ }^{\dagger}$
}

\section{CONTENTS}

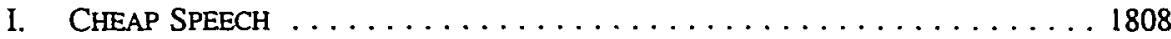

A. Music and the Electronic Music Databases . . . . . . . . . 1808

1. The New System . . . . . . . . . . . . . . . . . . 1808

a. What It Will Look Like . . . . . . . . . . . . . . . 1808

b. Why It Will Look Like This . . . . . . . . . . . 1810

2. How the New System Will Change What Is Available . . . . . 1814

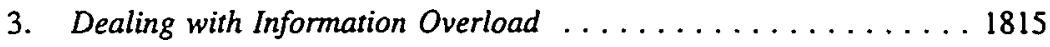

4. Will Production Companies Go Along? . . . . . . . . . . 1818

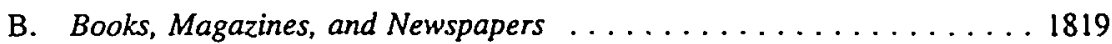

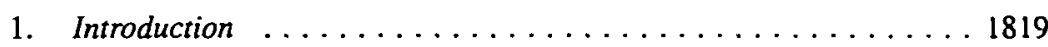

2. Short Opinion Articles and Home Printers . . . . . . . . 1820

3. Cbooks and Books, Magazines, and Newspapers . . . . . . 1823

4. How the New Media Will Change What Is Available . . . . 1826

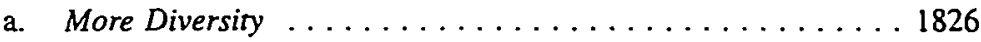

b. Custom-Tailored Magazines and Newspapers . . . . . . 1828

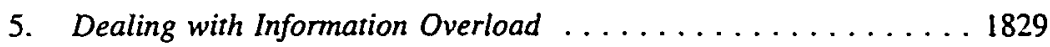

C. Video (TV and Movies) ..................... 1831

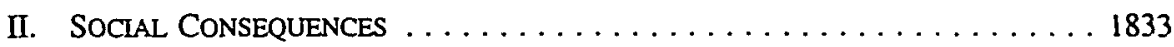

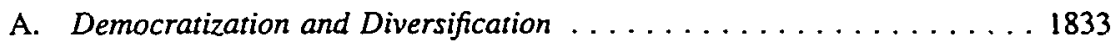

B. Shift of Control from the Intermediaries and What It Will Mean . . . . 1834

1. Shift of Control to Listeners ... . . . . . . . . . . . 1834

2. Shift of Control to Speakers: The Decline of Private Speech

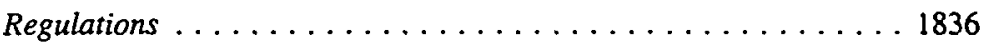

C. Poor Consumers . . . . . . . . . . . . . . . . . . . 1838

D. What Will Happen to Advertising (Both Commercial and Political) . . 1841

i Copyright $\odot 1995$ Eugene Volokh <volokh@law.ucia.edus. Acting Professor, UCLA Law School My thanks to Akhil Amar, Laura Brodbeck. Eugenia Gershman. Haym Hirsh. Judge Alex Kozınska. Dr. William Shor, Gail Standish, and Alexander Volokh; and, of course. to my mother Anne and especially my father Vladimir, at whose knee I first learned about computers. 
III. A FEW Words ABout the New Media AND the FIRST AMENDMENT $\ldots . .1843$
A. Existing Flashpoints $\ldots \ldots \ldots \ldots \ldots \ldots \ldots \ldots \ldots \ldots \ldots \ldots \ldots \ldots \ldots$
B. A Rosy Future . . . . . . . . . . . . . . . . . . . 1846
C. A Possible Dark Side . . . . . . . . . . . . . . . . . . . . . . . 1848

It's easier for the rich to speak than it is for the poor. It's also easier to speak if what you're saying, or singing or drawing, has mass appeal. Publishers will only invest in a product if the expected returns exceed the expected costs. If your work lacks a wide audience, publishers may be hard to find; and even if you can get a small publisher to back you, distributors may be unwilling to let you use their scarce shelf space. Getting access to nationwide radio and TV is harder still. People with unorthodox tastes lose out, and even those in the mainstream suffer when potentially interesting work isn't produced because of (rational) predictions that it won't be a hit.

Many have pointed to these problems-the bias in favor of speech of the rich, or of speech endorsed by the rich, and the relative blandness of much mass media." The perfect "marketplace of ideas" is one where all ideas, not just the popular or well-funded ones, are accessible to all. To the extent this ideal isn't achieved, the promise of the First Amendment is only imperfectly realized. And some suggest that because current First Amendment doctrine is premised on an open-market metaphor that isn't valid, the law should be adapted to this brutal reality. ${ }^{2}$

My thesis is that (1) these two problems are directly linked to the fact that speaking today is expensive; (2) new information technologies, especially the "information superhighway"3 or "infobahn," will dramatically reduce the costs of distributing speech; and, therefore, (3) the new media order that these

1. See, e.g., A.J. LIEBLING, THE PRESS 32 (2d rev. ed. 1975) ("Freedom of the press is guaranteed only to those who own one."); CASS R. SUNSTEIN, DEMOCRACY AND THE PROBLEM OF FREE SPEECH 58 (1993) ("Broadcasting access is the practical equivalent of the right to speak, and it is allocated very much on the basis of private willingness to pay."); Jerome A. Barron, Access to the Press-A New First Amendment Right, 80 HARV. L. REv. 1641, 1643 (1967) ("[A] comparatively few private hands are in a position to determine not only the content of information but its very availability."); Owen M. Fiss, Free Speech and Social Structure, 71 IOWA L. REV. 1405, 1413 (1986) ("[An unregulated marketplace of ideas will include] only those that are advocated by the rich, by those who can borrow from others, or by those who can put together a product that will attract sufficient advertisers or subscribers to sustain the enterprise.").

2. See generally SUNSTEIN, supra note 1, at 107-14; Fiss, supra note 1.

3. The information superhighway is supposed to provide cheap, extremely high-speed communication links to pretty much the whole country. Functionally, it should operate like the phone system, but because it will use fiber optics instead of wires, it should be able to transmit data much more quickly than phone lines can.

4. The word-in my view, a much snappier term than information superhighway-was apparently invented by Lynn Levine, director of market research and data sales at Warren Publishing, in 1993. E-mail from Brock Meeks, Publisher, Cyberwire Dispatch (online newsletter), to author (Oct. 27, 1994 \& Nov. 6,1994 ) (on file with author); Telephone Conversation with Lynn Levine (Nov. 7, 1994). The word's first appearance in publications available in NEXIS was on February 28, 1994; during the rest of 1994, there have been almost 800 references to it in those publications. 
technologies will bring will be much more democratic and diverse than the environment we see now. Cheap speech will mean that far more speakers-rich and poor, popular and not, banal and avant garde-will be able to make their work available to all.

To support this view, I describe in Part I what I think will be the likely information future and the market forces that will make it inevitable. I focus on how the infobahn will change the existing forms of communication: music, books, newspapers, magazines, and television. (Though the new, truly interactive media-electronic bulletin boards, Internet mailing lists, and Internet newsgroups-are a very intriguing topic, lack of space keeps me from discussing them. ${ }^{5}$ )

In Part II, I suggest some social consequences of these technological changes, each of which might be relevant to thinking about the First Amendment:

(1) Democratization and Diversification: Many more speakers will be able to make their speech widely available, including many who can't afford to do so today; and listeners will have much more choice than they have now.

(2) The Shift of Power Away from Intermediaries: Control over what is said and heard will shift from intermediaries-publishers, bookstore and music store owners, and so on--to speakers and listeners themselves. Private parties will thus find it harder to use their market power to stifle speech. Listeners will find it easier to become well informed about the issues in which they're interested. On the other hand, it will be easier for people to choose only the information they know they want, and to ignore other topics and other views. And the extra diversity of speech may reduce social and cultural cohesion.

(3) Mixed Effects on Poor Listeners: Poor listeners will be able to enjoy many of the benefits of the new order, but to some extent may be shut out from other benefits.

(4) Substantial Changes in Advertising in the Media: There'll be more noadvertising and low-advertising media; advertising will be better targeted to people; newspapers will lose a lot of classified advertising income; and political advertisements might change significantly.

Finally, in Part III I briefly explore some of the possible First Amendment implications of these changes. My ultimate conclusion is that the First Amendment of today will not only work well with the new information order-it will work better than it ever has before. But I also discuss ways in which the new technologies might undercut some of the assumptions that underlie the existing doctrine, and might lead to public pressure for legal changes.

5. See Lawrence Lessig. The Path of Cyberlaw, 104 Y ALE L.J. 1743 (1995). 


\section{CHEAP SPEECH}

\section{A. Music and the Electronic Music Databases}

\section{The New System}

\section{a. What It Will Look Like}

I want to start by discussing how the new technologies will change popular music. These changes may be less politically momentous than the similar changes that I think will happen in print and video. But the music industry will probably be the one that changes most quickly; and in any case, many of the things I say in this Section-about cost savings, increased choice, information overload, and so on-will apply equally well to the others.

The reasons for the changes will be very simple: There's lots of money in them. The existing music distribution system is inefficient, both for consumers and for musicians. For consumers, in particular, it has three problems:

Cost: Music costs more than it could. Consumers must pay about $\$ 8$ to $\$ 15$ for a new album, though musicians generally see less than ten percent of this in royalties. ${ }^{6}$

Choice: Consumers get a smaller selection than they could-many titles, especially ones that are relatively old or that appeal to fairly small markets, aren't available in most places.

Convenience: To buy music, a consumer has to take the time and trouble to go to the store.

And these problems translate into problems for musicians. High cost, low availability, and the inconvenience of buying lead to fewer sales. ${ }^{7}$

These inefficiencies aren't the result of some sinister plot or even of market irrationality. They are an inevitable consequence of the existing distribution system. People today must buy music on some tangible medium, such as tape or $C D$. This means they generally have to go to the music store (inconvenient), which has limited shelf space (lowering the choice). And the tangible medium has to be created, imprinted, distributed, and sold (costly).

The infobahn, once it brings high-speed two-way communications to private homes, is a far superior way of delivering music to the consumer. It will work something like this:

6. SidNEY SHEMEL \& M. WILliam KRASILOVSKY, This BusinesS OF MuSiC 4-5 (6th ed. 1990). Artists get $7 \%$ to $13 \%$ nominal royalties (less for new artists, more for the superstars), usually minus a $10 \%$ deduction-ostensibly, but not actually, to cover unsold records-and another $10 \%$ to $25 \%$ deduction for packaging. Id.

7. Consumer convenience is especially valuable to music distributors because people often buy music on impulse. If someone hears a song on the radio and wants to buy the album, the copyright owner would prefer that the listener be able to buy it immediately, or at least as soon as possible. If the listener won't go to a record store for another week or month, the song might be entirely forgotten. 
(1) Using your computer-or perhaps your TV set, with a keyboard, a touch screen, a mouse, or even voice activation-you access an electronic music database. This database (actually, there'll probably be several competing databases) will contain virtually all the music that's available in electronic form.

(2) You choose the music you want, by album name, by song title, by artist, by composer or songwriter, or by genre. You might even ask the computer for suggestions, based on the artists or albums you tell it you like. (The suggestions will be derived from judgments entered into the computer by reviewers.) You can also browse in some way, perhaps looking only at music of a particular kind, or music that has gotten good reviews. You can then play the music, to make sure you really want to buy it. ${ }^{8}$

(3) Once you decide you like it, you download the album to a digital recorder connected to your computer. Your bank account gets debited automatically.

This would mean:

Cost: Once the music is recorded-which even now can cost fairly little ${ }^{9}$ - the only significant other expenses will be advertising costs, royalties, the cost of electronic distribution, and the cost of the recording medium (which will be supplied by the customer). There'll be no need to spend money to create tangible recordings, ship them, and sell them. Assuming cheap electronic transmission (an assumption I'll try to suppor shortly), a CD-quality album may well cost as little as $\$ 3$ to $\$ 5-$ a $\$ 1$ royalty, ${ }^{10}$ plus amortization of the recording costs and advertising costs, plus the $\$ 1$ or $\$ 2$ that the customer will have to pay for the recording medium. An artist who's willing to pocket less money to get more customers might be able to charge $\$ 3$ or less.

Choice: You'll have close to the whole music library of the world at your disposal. Copyright owners will be able to sell to any infobahn-connected consumers, not just to the ones who have access to a store that's willing to stock the work. Because there'll be no shelf-space limitation-computer storage is cheap and getting cheaper-it won't matter how esoteric your tastes are; there'll be room for nearly everything."

8. The computer system will probably monitor how often you use the services, so that it can prevent you from using preplaying as a substitute for buying the album.

9. At the low end, recording can cost very little indeed. See David Rohde. Major Record Labels Tn To Copy the Success of Independents, Christian SCI. MONTTOR. Sept. 23. 1994, at 11 (noung that Nirvana's first album, Bleach, was recorded for \$800): Michael Snyder, Urban Folk-Rockers Swell Up. S.F CHRON., Apr. 17, 1994, at 35 (describing how album that was made by independent label for $\$ 900$ could be released with no alterations by major label. American Recordings).

10. See supra note 6.

11. Cf. Michael L. Evans, Role Reversal: Users Will Dictate the Development of Tomorrow's Real 
Convenience: You'll no longer have to drive to the music store or wait in line. You'll also be able to select what you want more conveniently, because you'll easily be able to pre-listen to what you're buying, ${ }^{12}$ and because you'll have readily available reviews. The copyright owners will benefit from this system too, because whenever consumers read a good review or like a song they hear on the radio, they'll be able to buy the music instantly, or at most have to wait until they get home.

\section{b. Why It Will Look Like This}

Music Database Operators: There's a lot of money to be made here. In the United States alone, there were over 475 million albums sold in the first six months of 1994, at an average suggested list price of over $\$ 10$ each, including both the more expensive CDs and the cheaper, lower sound-quality tapes. ${ }^{13}$ The sales volume should increase as costs go down, and the convenience of buying the product from home should raise volume even more. Skimming even, say, ten cents per transaction would mean, at today's rates, almost $\$ 100$ million yearly.

Mail-order CD catalogs-including computerized ones, such as cdconnection.com, which is accessible either directly through your modem or through the Internet ${ }^{14}$-are already the first step toward the system I describe. They attract customers by offering a large selection, ${ }^{15}$ slightly lower prices, ${ }^{16}$ and the convenience of home shopping (partly countered by the inconvenience

Estate, NAT'L REAL EST. INVESTOR, Sept. 1994, at 97, E\&Y-4 (describing how IBM and Blockbuster Entertainment's plan for on-demand inventory, where distributors deliver music and video electronically to stores, which then record it onto tangible media, may eliminate need to carry physical inventory); infra note 15 (describing how mail-order $\mathrm{CD}$ facility provides more titles because it lacks shelf-space limitations and inventory costs).

12. Some music stores-for instance, Borders Music and Blockbuster Music-already let you pre-listen to albums; you take a $C D$, give it to the attendant, the attendant puts it into a $C D$ player, and you sit there and listen to it. Still, it should be more convenient to pre-listen at home, where you don't have to deal with the attendant, wait in line if all the listening stations are busy, or spend $\mathbf{4 0}$ minutes sitting in the music store to hear the whole album.

13. Recording Industry Announces Midyear Growth, PR NEwswIRE, Aug. 11, 1994, available in LEXIS, News Library, Curnws File.

14. See Dan Hontz et al., Let's Go Christmas Shopping; Mall-Hopping Easy with Your Computer. ARIZ. REPUBLIC, Oct. 17, 1994, at E1; see also Marilyn A. Gillen, Online Retail Seeks Co-Existing Niche, BILlBOARD, Mar. 18, 1995, at 12 (describing cdnow.com, a competing service).

15. Cdconnection.com, which lets you order CDs from your computer but delivers them to you through normal mail, boasts over $100,000 \mathrm{CDs}$, covering the entire catalogs of all U.S. major labels and more than 2000 independent labels, plus several thousand import CDs. I had looked for years for one album-Lconard Cohen's New Skin for the Old Ceremony-and finally found it there.

16. See Stephen Advokat, Music for a Song?, CHI. TRIB., Oct. 11, 1993, at Cl. Cdconnection salls a substantial fraction of its CDs at $\$ 8.50$ to $\$ 10.50$, a good deal less than what they cost at many stores, though it also charges a $\$ 3.50$ flat fee for delivery (regardless of how many CDs you buy). According to cdconnection's online promotional materials, the price savings are due to lack of inventory costs and to the service's ability to shop among various suppliers. 
of having to wait for the CDs to arrive by mail ${ }^{17}$ ). Direct downloading should provide even greater cost savings, selection, and convenience.

Setting up a music database shouldn't be much harder than starting a mailorder $C D$ business today; and it should be much easier than starting a chain of music stores. Like the U.S. Postal Service, the telephone system, or the Internet, the infobahn should let any business be accessible through it. ${ }^{18}$ The database operators will have to buy computer equipment and design some software, but this shouldn't cost much. Even a database operator who gets only, say, $1 \%$ of the total market can make almost $\$ 10$ million yearly by charging a $\$ 1$ markup (which will still save consumers a lot of money). Ten million transactions yearly - thirty thousand daily - can easily be handled even today with fairly cheap equipment. ${ }^{19}$ And the low cost of setting up a database should keep competition high and consumer prices low.

Copyright Owners: There's also profit here for copyright owners. The new system will let copyright owners exploit markets that are closed to them now: people who would pay, say, $\$ 5$ for electronic delivery of an album but not $\$ 10$ for the album in the store (cost); ${ }^{20}$ people who don't have access to stores that stock the album (choice); and people who otherwise wouldn't take the trouble to go to the record store, or who may want to buy an album they hear on the radio but forget about it by the time they get to the store (convenience). And the electronic database operators would easily be able to pay the copyright owners royalties as high as what the owners get from music store sales, if that's what it takes to get the owners to sign up.

This will become especially true when, as some copyright owners join, others will find themselves pushed by competitive pressures to do the same. Once even a few albums become available for $\$ 5$ rather than $\$ 10$, albums that sell for $\$ 10$ will be at a significant disadvantage. Though music isn't fungible-loyal fans of New Kids on the Block might not think Tom Waits an adequate substitute-some product substitution will doubtless occur."

17. Cdconnection promises delivery times of one to two weeks to the westem United States. and two to three weeks to the eastern.

18. See Computer Science \& Telecomaunications BD., Realizing the information future: THE INTERNET AND BEYOND 30-38 (1994).

19. Storage of the music shouldn't be a problem. either. While the central databases will need a lot of storage, disk space today costs less than $\$ 1$ per megabyte, down from a bit under $\$ 2$ per megabyte a year before. See Peter Baum, High-Capaciry Hard Drives: Big Gigs. MACUSER. Oct. 1994, at 92. A 50minute album today takes a bit less than 30 megabytes (taking advantage of compression), which translates into a one-time cost of $\$ 30$ per album. See The Internet Multicasting Service, INFO. ACCESS, Feb. 18. 1994, at 10 .

20. Actually, the $\$ 5$ figure is for electronically delivered digital-quality music, while the $\$ 10$ figure includes both tapes (which are cheaper but of lower quality) and the more expensive CDs. People who insist on digital music may actually see a greater disparity: $\$ 5$ for home delivery versus $\$ 12$ to $\$ 15$ for $C D s$ in stores.

21. Some people to whom I've described this theory have suggested that copyright owners won't license their music for electronic distribution because they fear copyright infringement. Once music is electronically available, the argument goes. people could buy it once and then uploand it to some computer bulletin board, or sell bootleg copies via e-mail. Copyright owners will therefore be reluetant to allow 
Consumers: As I mentioned before, consumers can also benefit greatly from the new system. True, any change-especially one involving computerization-risks alienating customers, but the new system can be made very user-friendly. ${ }^{22}$ The system needn't be any harder to use than an ATM; and, as with the ATM, which has probably saved billions of person-lunchhours per year, the new system's benefits should be substantial enough that people will learn to use it.

Moreover, the physical advantages of music store layout-the ability to browse, and the possibility of stumbling over something good that one hadn't even thought of buying - could be made available on the home computer, too. The software could easily have a general "Browse" (or "Browse The Kind Of Music I Like") feature, if this is what users want. The software could also have other useful features-such as a convenient pre-listen mode, or crossreferences to reviews ${ }^{23}$ - that many music stores don't have. And if people really need human help, the software could, at the touch of a button, switch to a voice connection with an operator at the central database location. ${ }^{24}$

electronic music distribution.

But while electronic copying is indeed a serious threat to music copyright owners, this threat will exist whether or not the music is available in some central database. Even without an electronic music databaso, a pirate could easily go to the store, buy a $C D$, and make many copies of it on his DCC or Minidisc recorder. The electronic databases might make commercial piracy more tempting, because they will increase the number of people with digital players, who are the pirates' potential customers. On the other hand, some of this effect may be counteracted by the lower costs of legitimate buying through the databases. Pirates will thrive more when their rip-offs are competing with $\$ 10$ albums than with $\$ 5$ albums.

The music industry's reaction to DAT (Digital Audiotape) recorders, the first digital-quality home recording medium, is worth noting. When it became likely that home digital recording could let people easily make CD-quality copies of music, the music industry and the DAT industry agreed to a compromise, embodied in the Audio Home Recording Act of 1992, 17 U.S.C. \$\$ 1001-1010 (Supp.V 1993). The Act (1) legalized home noncommercial copying; (2) taxed DAT recorders and blank DATs, with the proceeds going to a fund to compensate copyright owners for the expected losses due to home copying; and (3) required DAT recorder manufacturers to design their recorders in a way that limits the possibility of largescale copying.

A similar solution might be set up for the electronic music databases. The music industry may be able to push through a law that would compensate for possible copying losses by: (1) requiring an extra royalty payment on each electronic sale, and (2) requiring, say, designers of e-mail systems or bulletin board systems to put in checks that would make unauthorized copying harder. Cf. WORKINO GROUP ON INTELLECTUAL PROPERTY RIGHTS, INTEllectual PROPERTY AND THE NATIONAL INFORMATION INFRASTRUCTURE 125-30 (July 1994) (suggesting regulations that restrict pirates' ability to profit from now technologies). This is hardly a foolproof solution, but it might provide some protection for copyright holders while still allowing them to exploit a powerful new sales tool.

22. Some music stores already have computerized music catalog machines (called Muzcs), which let customers search through information on 80,000 albums and videotapes, by performer, by composer, or by album. The user makes his selections by touching the screen and, when a name is called for, typing on a keyboard. See Ken LaFave, Muze System Takes Classical Music Lovers to Mount Olympus of CDs, PHOENIX GAZETTE, Apr. 26, 1994, at D3. The interface is clear, and the display is full color, with graphics.

23. Cdconnection.com's main information screen asserts that its system contains 50,000 ratings from fellow customers, and 26,000 professional ratings from the All-Music Guide. You can look up the ratings easily as you browse through the CDs.

24. Some consumers might actually enjoy going to music stores, either because they like the atmosphere, because they prefer being around other people rather than closeted at home, or because thoy like to go to music stores with friends. Movies, for instance, haven't been entirely supplanted by VCRs, in part because of the better picture and sound quality, but in part because people like going to the movies. 
Technology: The new setup will require a good deal of new technology, but what's not here yet is coming soon. Digitally recorded music is simply a collection of data, no different (from the computer's point of view) from your WordPerfect document. Music is already sent through the Internet. ${ }^{25}$ There's no reason it can't be sent down the infobahn to your home. ${ }^{26}$

Once the music arrives-in data form-at your home, it will need to be recorded on some high-quality medium. ${ }^{27}$ Two familiar media are nonstarters: Normal analog audiotape is too low-quality, and today's CDs are read-only. But two recently introduced technologies-digital compact cassettes (DCCs) and MiniDiscs-might have what it takes. They both provide sound quality as good as that of a CD; you should be able to download music to them from your home computer, and then play it at home, in your car, or in your Walkman. Today this equipment costs a lot, ${ }^{28}$ but prices are expected to fall as the technology improves and economies of scale kick in, ${ }^{29}$ just as they did for normal $C D$ equipment. ${ }^{30}$

But even if one sees going to the music store as a pleasure rather than an inconvenience, there will probably be few people to whom it will be worth the extra cost. People can socralize with friends, or mingle with strangers, in lots of other places. If home access provides a better deal on music, most people will just buy the music at home and do their socializing at a restaurant or the beach.

25. Pauline Tam, An On-line Link to Top Tunes Is Soon To Boom. Vancouver SUN. Aug. 2, 1994. at $\mathrm{C} 4$.

26. Today such a transmission would take quite some ume, because it goes over comparaluvely slow phone lines. Id. (noting that a three-to-four minute song takes anywhere from ten minutes to several hours to download by phone). The whole point of the infobahn, though, is to change all that. Data can be sent much more quickly through fiber optics than through wires; though no one is quite sure people are generally expecting speeds tens of thousands of times greater than those of phone lines. which now generally ship about 1000 bytes per second. See, e.g., Robert Sanford. Test Starts on Fiber Optic Loop. ST. LOUIS POST-DiSPATCH, Oct. 8, 1994, at 9A (giving factor of 10,000); A Superhtghway Shoricut. New ORLEANS TIMES-PICAYUNE, July 15, 1994, at B6 (giving factor of 500,000). Cable TV wires can already be used for data transfers 50 times faster than those over phone lines. Paul Furhi. Wirng $U_{p}$ Washington. WASH. POST, July 4, 1994, Business Section, at 1: George Gilder's Telecosm. ForBes, June 6, 1994, at $115,122-23$ (describing wire cable services already developed by several telecommunications companies).

27. Actually, you might even skip the recording step and instead play the musie directly from a central database (just as you could today listen to music over the phone. only with much better sound quality). You might then be charged on a per-play basis rather than on a once-per-album basis.

You'll still need to record the music, though, if you want to listen to it away from your infobahn connection, say in your car. And if transmission costs are high enough, you might prefer to pay them only once when you download the album, rather than every time you listen to it.

28. MiniDise recorders/players now cost \$800; DCC recorders/players cost \$400. Personal Technology: Sony's New MiniDisc Expensive but Versatile, ATlanta J. \& Const., Oct. 23. 1994, at P6; Philips Defers DCC Intros, CONSUMER ELECTRONICS, Sept. 12, 1994, at 37. Blank MiniDiscs stan at S14 cach, blank DCCs at \$8.50. Joseph Palenchar, Sony Takes the Lead in Digutal-Audto Fomat Bartle. ElEctronic Bus. BUYER, Nov. 1993, at 79.

29. Debbie G. Block, MiniDisc Music Promotion Pays Off. Plus High Hopes for Dasa Applications, TAPE-DisC BuS., Sept. 1994, at 14, 36.

30. Prices of CD players came down from about $\$ 1000$ in 1983 to as low as $\$ 100$ in 1993. James Bates, Old Recordings Are Music to Dunhill President's Ears, L.A. Times, Dec. 18, 1988, \$4, al 9; Steve Gross, Expo To Feature the Latest in Computer Technology: STAR TR1B.. Miny 2, 1993, at 3D. The cost of producing CDs fell from $\$ 3.50$ in 1985 to $\$ 1.75$ in late 1987 , and to a bit under a dollar by late 1991 . See Compact Discs: Turning Down the Volume?. ECONOMIST. Nov. 21. 1987. at 68 (reporting 50\% reduction in production costs from 1985 to 1987): Richard Harrington. The Vinyl Days. WASH. POST. Oct. 26, 1986, at F1, F6 (giving figure of \$3 as of late 1986); Kenneth Broad, CD Clubs Offer Deals that Consumers Can't Refuse, BILLBOARD. Oct. 19. 1991, at 11 (giving figure of 90 cents as of late 1991). 
To use this system, people will need computers, but there are already an estimated thirty million home computers installed today. ${ }^{31}$ The cheapest ones now cost about $\$ 700,,^{32}$ and, of course, this money will buy you many more features than just home music delivery.

Moreover, even people who can't afford a home computer and a home digital recorder might still use the system through public music vending machines. These machines may cost more than the home versions, because they'll need to be more resilient (and probably more theft- and vandalismproof); a fragile keyboard interface might have to be replaced by a touch screen interface, or by something similarly robust. Still, this shouldn't be especially difficult or expensive-consider ATMs, video games, and public lottery ticket machines. So long as there are millions of people who don't have home computers and home digital recorders, there'll be plenty of incentive to develop these technologies. Indeed, some music stores already have computerized music catalog machines (called Muzes) ${ }^{33}$ that have these features-the music vending machines would basically be Muzes, plus an infobahn hookup, a credit or debit card reader, and a recorder.

Finally, it shouldn't be hard to charge people electronically for using the service. The system could ask for a credit card number when you access it-much as is done today for phone sales, or for cdconnection.com computer sales-and confirm it while you're shopping. Better yet, it could charge you through your infobahn provider, much as 900 numbers now charge through the phone company. Music vending machines could accept credit cards or debit cards. And even more convenient forms of electronic payment may soon be available; electronic payment could be a boon to many businesses, and the market demand for it has generated a good deal of research and investment. ${ }^{34}$

\section{How the New System Will Change What Is Available}

The new distribution technology will do more than just make music cheaper and easier to get. It will also radically change what music is available.

I've already mentioned one way this will happen: The music databases will provide access to albums that stores otherwise wouldn't stock. Even if there are 50,000 fans of a particular kind of music throughout the country, a music store might expect there to be only a handful of these people among its customers. It can't afford to use shelf space for material that so few people

31. James Flanigan, Big Money Makes a Long-Term Bet on New Software for Electronic Teaching, L.A. TIMES, May 1, 1994, at D1.

32. Barry Cooper, Simple Needs? Try Windows Altemative, ORLANDO SENTINEL, Oct. 30, 1994, at H4 (describing "Leading Edge" IBM PC compatibles).

33. See supra note 22.

34. See, e.g., Funny Money, ECONOMIST, Sept. 10, 1994, at 74, 74 (describing research on secure, anonymous instant electronic payment). 
want. But electronic databases can carry even albums that appeal to only a tiny fraction of the market. The result will be more diversity for the listeners (even if not all of them take advantage of this diversity).

But electronic home distribution will do more than eliminate the bottleneck of music stores. It will also greatly reduce the power of the music production companies (the "labels").

Electronic distribution will drastically lower up-front costs. Even today an artist can make a commercially viable master recording relatively cheaply. ${ }^{35}$ With electronic distribution the cost will be even lower-once the master is made, there are no tangible copy production, distribution, or sales costs. An artist will no longer have to persuade a production company that his product is worth the investment. He'll be able to create it and submit it to the electronic databases himself; and once it's in the databases, the work will be as available as if it were in every music store in the country.

Many artists will probably still prefer that someone else pay for recording and editing the album, especially if they want a more-frills recording, and they'll probably like to have someone invest in advertising. Labels will thus still survive, and the artists will still have to persuade the labels that their works will sell enough to justify investment.

But the needed investment will be much less than it is today. Less money will have to be recouped for production expenses, so the labels will be more willing to back material that they think has a small audience. Even if no one is willing to invest, the artist could still pay for the recording himself, go without advertising, and hope it sells through word of mouth, good reviews, or radio play (especially through custom-mix radio, which I describe below). ${ }^{36}$ Advertising is better for the artist than no advertising; but no advertising on the infobahn is still better than the current system, where without a label an artist essentially can't make the music available to the public at all.

\section{Dealing with Information Overload}

The great obstacle to consumers getting what they want will no longer be that there are too few products available; it will be that there are too many. The new system, by reducing barriers to entry, will make much more material accessible to consumers. Some of it will be good; most will be junk.

This, of course, isn't a new problem. Tens of thousands of books and CDs come out yearly. Most of us have had the experience of going to the store and not knowing what to choose. But we've made do, largely because the information overload has spawned professionals-reviewers, radio

35. See supra note 9.

36. See infra notes $40-45$ and accompanying text. 
programmers, and decision makers at the record stores and the labels-who help us wade through the material. These people's job is to find what they think we'll like most, and tell us about it, play it for us so we can decide for ourselves, or try to sell it to us.

The new system will reduce the role of the record stores and the labels, but the other sources of information, such as reviewers, will remain. Rather than sending its work to production companies, hoping for a contract, a musical group will send it to reviewers. The reviewers will probably specialize in particular genres, and there will probably be quite a few of them, of varying reputations.

Some of these reviewers will, like music reviewers today, write for newspapers, magazines, and such. ${ }^{37}$ Other reviewers will select albums that they recommend and e-mail sample songs to their clients. The clients will then be able to listen to the songs at their leisure, and, if they like what they hear, buy the album (perhaps after first listening to it) at the touch of a few keys.

Still other reviewers will write brief reviews-perhaps even just give numerical ratings--for the music databases; they might also compare the music to other albums or artists. ${ }^{38}$ This will let database customers search for, say, "New Reggae that has gotten a thumbs up from at least two reviewers," or "Songs that someone who likes They Might Be Giants might enjoy." This class of reviewers will probably be paid by the music database operators. ${ }^{39}$

Custom-Mix Cable Radio: The most valuable review service, though, should be something akin to cable radio today. The virtue of radio as a selection tool is that, because the play list is ultimately outside of your control, radio familiarizes you with material you didn't know about. This, of course, is also its vice. You have some ability to select what's played-you can listen to a given station or a given show. But the selection is limited. Even in a big radio market you might find that no station quite satisfies you.

What one would optimally want, I believe, is the ability to specify the radio mix more precisely, without sacrificing the element of the unexpected and new that radio can provide. One would like to be able to say, for instance: "I'd like a mix of '60's rock, rock ballads from all decades, bluegrass, songs recommended by a Rolling Stone reviewer, and songs that someone who likes the Talking Heads, Paul Simon, and Concrete Blonde might like. I'd also like

37. Their advice, however, will be more effective than that of reviewers today, because it will be easier for people to act on the advice. If someone reads a good review, he can instantly-or at least not much later, if he's not near his computer at the time-listen to the album, and, if he likes it, buy it. Today, a reader will likely forget the good review by the time he next goes to a music store.

38. Cf. supra note 23 (describing cdconnection.com's computerized mail-order $C D$ database, which includes both reviews from listeners, solicited by cdconnection, and preexisting professional reviews).

39. While this creates a moral hazard-the music databases want to sell as much material as possible. and might pressure reviewers to give good reviews-the music database owners will also be kcenly conscious of the information overload problem. If they give consumers consistently reliable advice, the consumers will be more likely to buy the material that's recommended. If the advice becomes known as unreliable, consumers might not buy at all, or buy less often than they otherwise would. 
a small part of the mix to be random rock. And no Steely Dan! ${ }^{* 0}$ People would prefer this approach because it maximizes the chances that they'll like what they hear. One doesn't have to be particularly musically literate to know roughly what one enjoys, and to want to hear more of it.

It should be easy to get such a mix piped into your home. You could configure your preferences on your computer, and when you choose "home radio" mode, the computer would pick up a semi-random mix from the electronic databases and play it for you. Within the boundaries set by your preferences, the music would be selected based on the reviews stored in the databases.

Because you can pay for the music directly, you'll have the option of either a free service with commercials, or a paid service with no commercials. There's no reason to think the paid service would be very expensive, since there'll be no transmitter and FCC license to amortize, and since the copyright owners, interested in selling albums, will likely charge little for the rights. Cable radio is already available in some markets, though of course without the preference configuration system; it costs $\$ 5$ to $\$ 10$ per month."

You could also set up your computer to automatically store a mix every morning onto a DCC or a MiniDisc; then, you could take it into your car and play it all day in place of wireless radio. ${ }^{42}$ It might bother some to have to pop in a new cassette or disc every night and take it to the car every morning. Nonetheless, this extra effort shouldn't be prohibitive, especially since investing this effort could substantially increase listening pleasure. ${ }^{43}$

If a reviewer has 10,000 subscribers-and recall that the market is nationwide-he can make a decent living charging them $\$ 5$ to $\$ 10$ a year, plus copyright clearance costs, for a custom-mix service based on his reviews. Even with 1000 subscribers, the reviewer can make some money for not very hard work. Alternatively, reviewers can accept advertising, or take money from people who want their material reviewed. Some people might not trust reviewers paid by the musicians, ${ }^{44}$ but subscribers will be able to choose

40. Some people might actually like a Top 40-iype program, bocause they want to hear the things their peers are hearing. But even they might enjoy combining Top 40 songs with their own favonte matenal in some sort of custom mix.

41. Paula Bemier, Music Choice Jams with Digital Radio, TelepHony, May 2, 1994, at 42

42. Getting the custom-mix radio sent directly to your car will probably be too expensive. Maybe some day using wireless private lines will be as cheap as using the fiber opties of the infobahn, but that day may be quite some time from now.

43. Note, incidentally, that if custom-mix radio gets popular enough, cars mught concetvably be built to accommodate it; they might have built-in memory, and some son of plug-in (or even wireless) downloading mechanism that can be used while the car is parked at home. (Short-distance wireless communication is cheap, which is why you don't have to pay cellular rates for your home portable phone). Note also that people who like news interspersed with their music needn't despaur: Once the service becomes common, manufacturers may sell car systems that play a recording for a while and then switch to news broadcasts.

44. Cf. 47 U.S.C. § 317(a) (1988) (prohibiting "payola"-payment to radio stations for playing particular material-unless this is disclosed to the audience). But of. R.H. Coase, Payola in Radio and Television Broadcasting, 22 J.L. \& ECON. 269. 318-19 (1979) (suggesting that undisclosed payola may 
among those reviewers paid by musicians, those paid by subscribers, and those funded by advertising. ${ }^{45}$

Of course, like the other screening mechanisms, this will give some people-no longer the labels but now the reviewers-some power over what people will hear. A band that once complained, "Our music is brilliant but the producers are keeping it off the market," will instead say, "Our music is brilliant but the reviewers can't appreciate it."

The power of reviewers, though, is based on people's approval of their tastes. Maybe the people's trust is misplaced, but it's hard for artists to complain that the reviewers' power is illegitimate. Moreover, the reviewers' power is much less exclusionary than the power of the labels. If I don't like one reviewer's taste, I can easily switch to another. If reviewers are neglecting material that at least some listeners-even small groups of listeners-would like, other reviewers will step into the breach. And the low cost of providing reviews means even small markets should have quite a few reviewers serving them.

\section{Will Production Companies Go Along?}

I mentioned above that electronic music databases will succeed because both copyright owners and consumers can benefit from them. But many sound recording copyrights are owned by the music production companies. If, as I suggest, production companies will be hurt by the new system, will they be willing to license copyrights to businesses that will likely displace them?

Production companies may well be reluctant to let the electronic music databases get off the ground; but it seems to me competitive pressures will ultimately force them to go along. The new system gives copyright owners a new way of exploiting markets they otherwise couldn't reach. Even if it will prove generally bad for labels in the long term, some small labels-which may have their sights set more on selling their existing stock rather than on the long run-will want to take advantage of it. Musicians signing new recording deals may want to take advantage of it, too, because the new system is definitely in their interest; if the musician has a good enough bargaining position, the label may have to participate even if it doesn't really want to.

Also, the fact that copyrights in musical works aren't truly exclusive may play a role. A musician can record a song without the composer's permission, so long as he pays a compulsory royalty (today, 6.6 cents per song per

benefit consumers).

45. This is already happening in part with online services: One leading service. Prodigy, carries intrusive advertising-advertising that users must see, as opposed to advertising they choose to look at-while two others, America Online and CompuServe, do not. See Vic Sussman, News of the Wired, U.S. NEWS \& WORLD REP., May 16, 1994, at 60, 62. 
copy). ${ }^{46}$ Of course, people might still much prefer the Beatles' Let It Be to Volokh's Let It Be; but the fact that new covers of old standards constantly come out will weaken somewhat the copyright monopolist's hold on the market.

Finally, once the system gets off the ground, the lower cost and extra convenience to consumers will lead to pressure for reluctant labels to participate. Even consumers who today are willing to pay $\$ 10$ for albums at stores may become reluctant to do this once they get used to paying $\$ 5$ from home. Though the existing market players might not like the system, I think they'll have to accept it. To take an analogous case, prices often fall not because sellers prefer that they fall, but because new entrants, or small vendors looking for market share, drive the prices down. While large producers may try to stop this, they generally can't.

\section{B. Books, Magazines, and Newspapers}

\section{Introduction}

Text is even easier to send electronically than music, because it requires much less space, and therefore less transmission time; it can even be transmitted feasibly through today's relatively slow communications mechanisms. Some newspapers already put much of their news online. ${ }^{37}$ There are already special electronic-only news services, such as Clarinet Communications' ClariNews, which contains everything from business news to sports to a few columnists (such as Miss Manners) and cartoons (such as Dilbert and Bizarro). ${ }^{48}$

There are also libraries of electronic books. Project Gutenberg at Illinois Benedictine College has created a database of 160 books, including the Bible, Alice in Wonderland, and the collected works of Shakespeare, all available free on the Internet. ${ }^{49}$ The Internet Bookstore service sells new books-though at the moment, rather few of them-from various publishers, including

46. 17 U.S.C. $\$ 115$ (1988) (compulsory license for compositions); 58 Fed. Reg. 58.282 (1993) (to be codified at 37 C.F.R. $\$ 307.3$ ) (setting rate at 6.61 cents, or 1.3 cents per minute of playing time-rounded up to next minute-whichever is larger). This applies only when a recording of the song has already been distributed, with the composer's permission, in the United States. 17 U.S.C. $\$ 115$ (1988).

47. Dana Blankenhor, Prodigious Bulletin Boards Are Prodigy's Growing Competution. Cul. TrIB., Oct. 2, 1994, § 20, at 7 (listing Chicago Tribune. New York Times, and others): Virgını Evereth. Status Report: U.S. Newspapers Online, DATABASE, Oct. 1994, al 14 (listing Allanta Joumal and Constzufton and others); Hanna Liebman, Newspapers Hit the Highway, MEDIAWEEK, Apr. 25, 1994, al 16 (listing San Jose Mercury News and Chicago Tribune); Christopher Lloyd, Are You Ready for the Future?. SUNDAY TMiEs (London), Nov. 20, 1994, $\$$, at 1 (listing Sunday Times).

48. Clarinet Communications Corp., ClariNews Public Access Newsgroups (1994) (on file with author): Peter E. Dyson, Publishing on the Internet for Fun and Profit. SEYBOLD REP. ON DEsKTOP PUB.. Apr. 4. 1994, at 3.

49. Lamont Wood, Throwing Out the Rule Book on How To Read: Project Bulding an On-line Library, CHI. TRIB., Oct. 2, 1994, § 20, at 6. 
Paramount MacMillan, Oxford University Press, and the National Review. The books sell for somewhat less than the print price. ${ }^{50}$

The problem, of course, is that computer screens are harder to read than books. Modern large-screen workstations, with black-on-white display and proportionally spaced fonts, are better than the old 24-by-80 displays that most of us still use. Still, they're not as easy to read as a book, and they certainly aren't as portable.

There are two ways to deal with this: Some text might be not only electronically delivered, but also printed out on home printers; and laptop computers might be made so readable and portable that reading text on them will be as easy as reading a book. I'll deal with these two possibilities in turn.

\section{Short Opinion Articles and Home Printers}

I suggested above that, in the coming years, more and more homes will have a computer, an infobahn connection, and probably a music recorder connected to the computer. But even more common than the recorder will be the laser printer. Laser printers can generate text that's as readable as what you see in a newspaper; today they cost as little as $\$ 400 .^{51}$ While people probably wouldn't like hundreds of unbound, single-sided, $81 / 2 " \times 11^{\prime \prime}$ sheets of paper coming off their printers-which is what a complete book or newspaper requires-one to five sheets should be no problem.

Many people make a living writing short, periodic articles. There are columnists, either daily or weekly, such as William Safire and Mike Royko. There are comic strip artists. There are also organizations, such as the American Civil Liberties Union (ACLU), the National Rifle Association (NRA), and many smaller ones, which periodically send out their ideas-or at least would like to send out their ideas-to their members or fellow travelers.

Electronic delivery, assuming it's cheap enough, is a perfect medium for these writers and their readers. The setup would be simple.

(1) A consumer will run a program on a home computer that will display a list of available columns. This list would be indexed by author, topic, and so on.

(2) The consumer can then choose a column; the cost of the subscription will be automatically transferred from his account to the writer's.

(3) Every night, or once every week, a column will be sent to the consumer's computer, which will automatically print it. ${ }^{52}$

50. The Internet Bookstore Opens for Business, LINK-UP, July 1994, at 21.

51. Laurent Belsie, Hot Competition: Computer, Accessory Prices Take a Cut for Buying Season, ChristIAN SCI. MONITOR, Sept. 9, 1994, at 9.

52. Consumers need not fear unsolicited "junk e-mail" arriving through this system; they can casily configure their home computers to print only those messages that they have actually requested. 
The writers win under this system, because they can reach readers whom they otherwise couldn't reach: people in areas where no newspaper carries the writer's column, and people who don't subscribe to a newspaper. Moreover, by cutting out the middleman, columnists may be able to get more per subscriber than they do today. And readers win too, because they can get columns that they otherwise couldn't.

Electronic delivery is also perfect for public interest organizations. Today, they have to communicate with people by mail, a costly operation. ${ }^{53}$ If the infobahn dramatically cuts the cost, they can increase their impact by writing to their members more often, and by reaching nonmembers, too. If delivering three or four pages costs five cents, the ACLU could offer people a weekly "ACLU Action Letter" for $\$ 2.50$ a year. Millions of sympathizers might well want to subscribe at that rate, especially if they could do so in minutes from their home computers.

Technology: There's every reason to think the cost of transmitting the text will be very low. Two information infrastructures of today are useful analogies: According to a recent estimate, the cost of transmitting 2000 bytes (about a page of uncompressed text), even using today's relatively primitive Internet technology, is about $1 / 6$ of a cent; $;{ }^{54}$ and local phone calls are already free. ${ }^{55}$ As newer, faster delivery methods come online, the cost of transmission should fall even below that of the Internet.

The big expense will probably be paper. Paper now costs about one cent per page. ${ }^{56} \mathrm{~A}$ daily one-page column might thus cost the consumer as little as two cents a day - one cent for the paper and one for the transmission cost and profit for the sender. This comes to less than $\$ 10$ a year. The per-item paper costs will go down if the consumer subscribes to more than one item, since the computer can fit several columns or comics onto one page. Even if the transmission costs are somewhat higher, the result should still be quite affordable.

Consumer Satisfaction: This format should also satisfy consumers. Print quality will be good, subscribing will be easy, and the columns will arrive automatically on the printer, with no extra keys to punch every morning. Some people might actually prefer a few pages of their favorite stuff to a thick newspaper they must unfold and search through.

Of course, some people will be unwilling to pay even pennies for the columns. They may already be subscribing to a local paper, which is full of

53. See Bill McAllister, Nonprofit Mail Discounts on Route to Cancellation: Thousands of Nonprofil Groups Facing Loss of Postage Subsidies, WASH. POST, May 11, 1993, at Al.

54. Jeffrey K. MacKie-Masson \& Hal Varian. Economic FAQs About the Intemer. J. Ecox. PERSP. Summer 1994, at $75,91$.

55. Long-distance calls are expensive, but computer networks already avoid this cost by having users connect to local computers and then routing the messages across the country using their own communications mechanisms.

56. Conversation: Saving Cash with Second-Time-Around Goods, INC., May 1994. at 162. 
columns and cartoons and other things. After paying $\$ 100$ to $\$ 200$ a year for the subscription, ${ }^{57}$ they may not want to pay more.

Nonetheless, the great majority of people do not subscribe to newspapers. Many of them might not much like print, but others don't want all the data newspapers provide-they may find it irrelevant, or they might get it from radio when they drive to work, or they might not have time to read the newspaper every day. They might well prefer paying, say, $\$ 25$ a year for the few columns and comics they really like.

Even people who already subscribe to newspapers may be willing to pay that much for the columns the newspaper doesn't carry. Twenty-five dollars a year is cheap as entertainment goes, especially when it's entertainment that the reader knows he'll enjoy, and that he can easily subscribe to on a whim. Some people may be deterred by the cost, but lots won't be.

Speaker Willingness: Finally, there should be no shortage of willing highquality speakers. Public interest organizations should be happy to use this medium, and they can certainly provide quality (if partisan) commentary to their subscribers.

The situation is different for existing columnists. William Safire and Judith Martin (Miss Manners), for instance, already appear in hundreds of newspapers. Their syndication agreements may contain exclusivity clauses ensuring that the columns won't appear in more than one newspaper in each market. These newspapers might be reluctant to let the columns appear electronically in the same markets that the newspapers serve.

Nonetheless, competitive pressures will eventually make more and more of the good columnists electronically available. Electronic suppliers could distribute columns with geographic restrictions: A consumer can subscribe in Las Vegas but not in Los Angeles. Columnists can thus give their newspapers exclusivity, while still taking advantage of markets in which their columns otherwise wouldn't run.

Newspapers might be hesitant to go along even with this scheme because the electronic distribution system competes with newspapers as a medium, and newspapers may be reluctant to give any edge to their competitor. But every subscriber for a one-cent daily column could be $\$ 3$ a year in a columnist's pocket. If the columnist can reach 100,000 extra subscribers-and millions of people read (not just have access to) the highest-profile columnists-that's a couple of hundred thousand dollars.

Persuading columnists to forgo this market could be expensive for newspapers. Some newspapers might get some columnists to agree not to publish electronically; more might get them to limit distribution to places where the columns are unavailable in print. But not all newspapers would be

57. The Los Angeles Times, for instance, costs about $\$ 200$ a year (for both daily and Sunday papers). Telephone Conversation with LA. Times Subscription Department (Nov. 13, 1994). 
able or willing to do this in the face of the substantial economic pressure on the columnist to go electronic.

Moreover, good opinion pieces don't cost a lot to produce. Not everyone can consistently write informative, readable prose, but neither is the talent remarkably rare. Tens of thousands of people can do the job. With the electronic medium, each of them will be able to throw a hat into the ring.

If the Safires and the Martins don't do it, others will. Of course, they'll have to find their audience, in competition with thousands of others. But finding this audience electronically will be easier than finding a comparable audience with newspapers; and even if most columnists fail, that'll just be because others will succeed.

The Survival of Newspaper Columns: Note that, unlike record stores-which I think will be largely displaced by the electronic music databases-opinion columns in newspapers will survive. People will still buy newspapers for news and will expect to get their familiar columnists, too. Moreover, an up-and-coming columnist may still prefer to be published by a newspaper, with potential access to millions of readers, instead of urying to find his own following on the electronic services. My claim is only that electronic opinion columns will thrive alongside newspapers.

\section{Cbooks and Books, Magazines, and Newspapers}

In the previous Subsection, I focused on short opinion pieces printed out on home printers; books, I suggested, couldn't be conveniently delivered this way. But home printers will become less necessary once computer screens are developed that are roughly as readable, portable, and lightweight as books. One possibility, which I call a cbook, would be a display that is the size of a small book, folds open like a book, and has the resolution of a book. The technology doesn't exist yet, but it seems within reach. ${ }^{58}$

You would connect the cbook to your home computer and use the computer to access an electronic database. This database would contain tens of thousands of books stored in electronic form. You'd select the one you want-searching by title, by author, or by subject-and download it to your cbook. Then you'd read it as you would a normal book, but pushing a button instead of flipping pages. There would be ways, of course, to do all the normal "features" of a book-go to a particular page, set a bookmark, highlight some text, write a note to yourself on the margin, and so on. ${ }^{59}$ And there would be other features normal books don't have:

58. See George Gilder, Digital Dark Horse-Newspapers. WhOLE EARTH REV., Summer 1994, at 23. 24 (describing current state-of-the-art, fiat-screen displays that are about $9^{-}$wide, $12^{-}$high, and $1 / 2^{-}$thick. and weigh just over one pound).

59. Highlighting and writing notes would require some son of electronic stylus that the writer could use to write on the screen, but these already exist. 
* You could search a book for a given word or concept much more easily than with traditional indexes.

* Foreign-language books would have built-in dictionaries.

* You could easily carry around hundreds of books; the only limit will be the size of your internal disk drive.

* Books could easily be updated to reflect new developments or to correct errors. ${ }^{60}$

* The book could be exhaustively footnoted without having the footnotes appear obtrusively on each page. And you could easily follow cross-references in the footnotes without keeping a finger on every page. $^{61}$

* Children's books could be more interactive.

Cbooks will also be especially useful for distributing magazines and newspapers. First, they'll save publishers a lot in printing and delivery. A typical issue of a monthly magazine, for instance, costs seventy-five to eighty cents to print and mail, but can be electronically delivered for pennies. ${ }^{62}$ Many scientific journals are already shifting into electronic distribution, in part because of the huge cost (several hundred thousand dollars a year) of acquiring all relevant journals for a university science department library. ${ }^{63}$ Competition will force publishers to pass some of these savings along to consumers, but even if they do, they'll still win, because as magazines get cheaper more people will buy them.

Second, cbooks will allow timelier distribution of the material. ${ }^{64} \mathrm{~A}$ Newsweek could deliver news to people that's genuinely current, rather than two or three days out of date. Newspapers could update their stories as news comes in, and would no longer have to be up to a day behind broadcasters. This will help the consumer as well as the publisher; and once some publishers do this, competitive pressures will push others to follow.

Finally, cbooks will give newspaper publishers access to geographical markets that are now closed to them. Today, only The New York Times, The

60. Suppliers can easily update the central database, so all future buyers will get the updated version. Suppliers can even update the book for people who have already bought it and downloaded it onto their cbooks. The publishers can set up a service to which any cbook owner can connect, perhaps every week or month, and automatically receive updates-for a charge-for all the books he owns. This service will be just like a pocket part for a legal treatise, but with no need to print, mail, and stuff, and no need for the reader to check both the main part and the pocket part.

61. Cbooks will also be able to support hypertext, which in the view of many is a much more useful way of organizing information than the conventional book. See M. Ethan Katsh, Rights, Camera, Action: Cyberspatial Settings and the First Amendment, 104 YALE L.J. 1681, 1700-02 (1995).

62. See Steven Barboza, The Price Is Right, Folio, May 1, 1993, at 58.

63. See Andrew M. Odlyzko, Tragic Loss or Good Riddance? The Impending Demise of Traditional Scholarly Joumals, INT'L J. HUM.-COMPUTER STUD. (forthcoming 1995), reprinted in ELECTRONIC Publishing Confronts ACAdemia: THE Agenda FOR THE YeAR 2000 (Robin P. Peck \& Gregory B. Newby eds., forthcoming 1995) (manuscript on file with author); Gary Stix, The Speed of Write, SCI. AM., Dec. 1994, at 106.

64. See Gilder, supra note 58 , at 24-25, 27-28. 
Wall Street Journal, USA Today, and The Christian Science Monitor are nationally distributed. ${ }^{65}$ Cbooks will open the whole country, and eventually the whole developed world, to all newspaper publishers. While many regional newspapers won't get much from this, would-be national publications-say, The Washington Post, or a liberal equivalent of The Wall Street Journal, or the entertainment section of The Los Angeles Times-definitely could. Foreign newspapers, which have a ready market of expatriates and others who are professionally or personally interested in the foreign country, could benefit as well. ${ }^{66}$

Technology: The cbook would cost much more than a typical book. The cheapest laptop displays wholesale today for about $\$ 1100$, with the price supposed to fall shortly to as little as $\$ 500$ to $\$ 700 .^{67}$ The price will probably fall further, but it seems likely it will always remain fairly high.

One could easily save that much, though, in lower costs for the actual literary works themselves. Working from a customary $10-15 \%$ royalty. ${ }^{63}$ and including a mark-up for editorial services and electronic database costs, books that sell today for $\$ 5$ to $\$ 20$ could sell for as little as $\$ 1$ to $\$ 4$ each. $^{69}$ And, of course, the reader will save the costs of driving to the bookstore, trying to track down a book that isn't on the shelves, and finding that the book he wants is out-of-print.

Scanning old books into computers is hard, but publishers must put virtually all new books into electronic form to print them. Publishers can easily send all new books to the electronic databases.

The cbook won't have the feel of a conventional book, even if it has the look. People who like feeling paper rather than plastic under their fingertips may always loathe cbooks, or so I've heard from friends with whom I've discussed this concept. On the other hand, some people will prefer cbooks to bulky, hard-to-unfold, ink-smearing newspapers. And while some will always appreciate paper books (though probably not all paper books) as objects of art, the main purpose of books is to communicate information. The cbook will be useful enough that many people raised on paper books will switch to it. But even those who wouldn't read it for themselves will buy it for their children,

65. Allen Neuharth, The State of News Standard Today Compared with Those in the "Golden Age". EDITOR \& PUBLISHER, Feb. 26, 1994, at 54.

66. See Bruce Cohen. Director, South Africa Weekly Mail \& Guardian. Speech to the First Pan-Arab Conference on Managing Newspapers in the Arab Wortd (Sept. 28-30. 1994) (explauning benefits of electronic distribution of Weekly Mail \& Guardian); E-mail from Bruce Cohen to author (Nov. 10. 1994) (on file with author).

67. John McDonough, Industry Focus: Components, COMfPUTER ReSeuler News. Mlay 23. 1994, at 150.

68. See Ron Scherer, Grisham, Crichton Books Serve as a Boarding Pass. Curtstian SCI. Movmor. Sept. 2, 1993, at 14 (giving 10\% figure); James Warren. Lucratwe Detours on the Information Superhighway, CHI. TRIB., Jan. 27, 1994, $\S 5$, at 2 (giving 15\% figure for hardcover books).

69. Cf. Alan Deutschman. Scramble on the Informanon Highway. FortuNE. Feb. 7. 1994. at 129 (making similar point). 
especially given the possible educational benefits of interactive cbooks. And the children, when they grow up, might not be as nostalgic for paper books as today's adults may be.

\section{How the New Media Will Change What Is Available}

\section{a. More Diversity}

Even more than with music, the lower distribution costs will change what is available, as well as how it's available. High distribution costs have meant that media organs-newspapers, magazines, radio stations, TV stations-control which commentators are available and which aren't. Media organs may control based on their own political opinions, and they also control based on what their readers are likely to want. Even if a million people nationwide want to hear the Libertarian-or Socialist-view of things, there may be too few such people in each major market to make it worthwhile for newspapers to carry columns that appeal to these readers.

Lower distribution costs mean columnists and organizations can thrive if they appeal to even as few as several thousand people. Say columns cost onehalf cent for transmission, one cent for paper, and one-half cent for royalties to the author. If even 30,000 people nationwide are willing to subscribe to a daily column-for about $\$ 7.50$ a year-the columnist will make $\$ 150$ a day, enough to keep body and soul together.

An organization like the ACLU, which might get one million subscribers, can make $\$ 3.5$ million yearly on these terms, enough to hire editors, writers, and news gatherers, and perhaps even fund the organization's other public interest activities. Poor speakers will get a soapbox; listeners with unusual tastes will find more material that will please them; and the mix of available commentary will be much less bland than it is today.

The same will happen for books. Besides making books cheaper and largely eliminating the problem of books being out-of-print, the new technologies will also allow more books to be published. Publication, in fact, will consist simply of the writer sending the book to some electronic databases. There'll be no publisher, no veto power on the publisher's part, and no need for the book to have mass appeal before someone will invest in it.

The story for newspapers and magazines will be somewhat different. Though their distribution costs will fall, their production costs will still be substantial. The news will still have to be gathered, written up, and edited. But the total costs will be lower than they would otherwise be, so publications will be easier to start and easier to keep profitable.

Some Examples: Electronically distributed short newsletters already exist today, though-for technological reasons-not yet in the form I describe. Fax newsletters are already used for timely, relatively low-cost distribution. 
(Though faxing may cost money for phone calls, it saves labor costs-stuffing envelopes, printing labels, and the like-because faxes can be automatically sent by computer.) Bankruptcy Creditors' Service sends specialized newsletters to creditors of debtors-in-possession. ${ }^{70}$ The Thoroughbred Daily News circulates a daily delivered-by-6-a.m. newsletter summarizing the previous day's racing." These services are expensive, but that seems to be just a function of what the market will bear. They can be cheaper if the author and the customers prefer: Some religious organizations, for instance, have started free religious fax newsletters for their congregants. ${ }^{72}$

Westlaw is another example. Westlaw has several databases-WLB (Westlaw Bulletin), WTH-CJ (Westlaw Topical Highlights on Criminal Justice), WTH-LB (Westlaw Topical Highlights on Employment Law), and others-that West updates daily with one-paragraph squibs on potentially important recent cases. The cases range from a few days to a few weeks old.

Using Westlaw's Westclip service, I've asked that new additions to those databases be printed daily to my local printer. I've also configured special queries of my own-for instance, to print every day all new cases on free exercise of religion. Each morning, I go to the printer and get new information that I might otherwise have never seen. It's like a daily newspaper chock full of articles for legal junkies like me.

Of course, this would cost me a fortune if West Publishing didn't give us teachers free access. But West lets me access this service for free only because the marginal costs of my use are very low. If West had to print and mail the results of my queries every day-which would cost them a lot in labor and postage-they'd almost certainly not make the service available free, even to law schools.

Likewise, Minnesota gubernatorial and senatorial candidates recently debated one another online, using an Internet mailing list. ${ }^{73} \mathrm{~A}$ moderator asked a question; the candidates gave their answers, in a few paragraphs each; and they then responded to one another. Each candidate entered a message or two each day. I suspect most of the "viewers" read the messages online, but many could easily have configured their mail systems to print the messages automatically, if that's what they preferred. ${ }^{74}$ The debate didn't change the course of the election-there were only 500 people watching — but it did show the power of electronic communications. Once the candidates agreed to

70. House of Fabrics Bankrupicy News: The By-Fax Newsletter. PR NewSwiRE Nov. 3. 1994. available in LEXIS, News Library, Curnws File (describing $\$ 30$ wockly plus fax charges).

71. Greg Boeck. Hollywood Park Scene of Star Rematch. USA ToDAY. Dec. 10. 1993. at 7C (describing cost as $\$ 364$ for six months).

72. See Richard Vara, Fax and Figures: Churches Untlize Popular Machunes. Hot's Curox., Oct. 2. 1993, at E1.

73. See Bob von Stemberg, Sparring in Cyberspace: Campaigns Jump on Intemet, STAR TRIB. (Minneapolis), Oct. 31, 1994, at 1B.

74. Even my free e-mail system. Pegasus Mail, has such an option. 
participate, no one needed to persuade the media that carrying the debate would attract enough viewers or readers.

Similarly, Patrick Crispen, a public-spirited student at the University of Alabama, recently ran a series of online Internet tutorials. ${ }^{75}$ Crispen's announcement of his tutorials generated 62,000 subscribers. ${ }^{76}$ Obviously, the number would have been lower had the tutorials not been free, and because of current Internet etiquette, he would have had a harder time advertising a payfor service. Still, Crispen has, with no expenditure other than his time-and his university's computer resources-drawn an audience many newspapers would envy. ${ }^{77}$

Finally, when reporters at The San Francisco Chronicle and The San Francisco Examiner went on strike in November 1994, the striking employees--unfazed by lack of the newspapers' printing plant and distribution network-produced their own paper, The San Francisco Free Press, and delivered it over the Internet. The electronic newspaper was the first to break a story, which got a lot of play during the November 1994 senatorial campaign, about Senator Dianne Feinstein's alleged employment of an illegal alien. $^{78}$

\section{b. Custom-Tailored Magazines and Newspapers}

But beyond increasing the number of publications, cbooks will also change the very concept of reading a magazine or a newspaper. No one wants to read, say, the whole Los Angeles Times, with all its stories about news, sports, entertainment, food, travel, cars, and so on. No one reads the newspaper cover to cover. People read most parts of some sections and some parts of others, and throw out the rest.

What people want are newspapers and magazines with stories about the things that interest them (just as they want radio with the songs they like). They may want a newspaper that has, for example, the top twenty international stories of the day (with a special focus on news from Africa), the top five national stories, the top five science stories, the top ten law stories, news about football and about the Los Angeles Dodgers, and, say, ten random stories just for the unexpected surprise. ${ }^{79}$

75. See Miguel Llanos, Newbies Flock to On-Line Class of Internet Basics, SEATTLE TIMES, Sept. 18, 1994, at D2. Each tutorial consisted of 20 or so messages, of about 100 lines each; the messages, about various aspects of the Internet, were delivered every couple of days.

76. E-mail from Patrick D. Crispen to author (Nov. 13, 1994) (on file with author) $(62,000$ subscribers from 77 countries).

77. The strain on the computer resources need not have been great, given that the messages could have been routed during off-peak hours.

78. Pickets Can't Stop Publications: Internet, Management, Strikers Offer Own Version of News, Hous. Chron., Nov. 4, 1994, at 4A.

79. After writing this Section, I learned that one such customized newspaper is being tested by the publisher of The Wall Street Journal. See Richard Tomkins, Media Futures: Enter the Bespoke 
Readers do want the stories to be professionally investigated, written, and selected, perhaps by the same staff that brings them the newspaper or the magazine today. But they want them in the mix they prefer. And newspapers already realize people want this-witness the local editions of various papers, such as the San Fernando Valley edition of The Los Angeles Times.

Today's newspapers and magazines are creatures of a particular economic fact of the print age: To print cheaply and distribute cheaply, you have to print many copies of exactly the same thing. If most readers in Los Angeles don't care about science or about Angola, the paper puts in few stories about these subjects, and the oddball readers lose out. On the other hand, O.J. Simpson stories fill the front page, and the handful of non-O.J.-trial-buffs must wade through them to find what they like.

Yet electronic distribution doesn't require uniformity. Letting a user configure his own mix of materials is a trivial software problem. Readers will set up this mix at subscription time; people who don't want to bother with this will get a default mix that they can change whenever they like. Moreover, the subscribers could mix stories from different sources-local news from The Los Angeles Times, international news from The New York Times, and national and business news from both The New York Times and The Wall Street Journal, to get two different perspectives.

\section{Dealing with Information Overload}

Opinion Articles: With opinion articles as with music, we'll soon have many more options than most consumers will want to slog through. There's something valuable-as well as limiting-in the fact that your daily paper offers four op-ed pieces rather than forty thousand.

But as I noted in the music discussion, information overload isn't a new phenomenon. There are far more books than any consumer can personally browse, and yet we're quite happy with this, and don't clamor for less selection. We generally prefer to go to bigger bookstores rather than smaller ones, even though smaller ones have done some extra preselection for us.

True, we partly rely on the screening done by publishers, who'll at least have rejected the total garbage, but we also rely on reviewers, word-of-mouth. our familiarity with particular writers and artists, the possibility of browsing. and advertising. These mechanisms will still exist for the new media, even if publisher selection doesn't. People will still read reviews and hear about good items from friends. People will also be familiar with existing popular columnists and existing organizations that are starting newsletters.

Moreover, electronic distribution can make possible new selection devices. One particularly useful new service-similar to the custom-mix radio I

Newspaper-Customers Will Get a Tailor-Made Information Senice. FIN. TIMES. Mar. 13. 1995, at 13. 
discussed above-would be a subscription that delivers a different column every day, perhaps selected by general topic or political perspective. Thus, together with my daily William F. Buckley, Libertarian Report, and Column Left/Column Right on the First Amendment, I could also download a different center-to-right-wing column every day, and twice a week random (but wellregarded) columns from all points on the spectrum.

When I find a column I really like, I might subscribe to it, or order a few more days' worth to see if I really like it. The service could be even cheaper than normal subscriptions, because the columnists would probably be willing to waive their royalties for the exposure the service would provide. The service might be cheaper still, or free but for the cost of paper, if the service takes advertising, or takes money from the columnists in exchange for reprinting the columns. This latter approach will create a potential conflict of interest, as well as a barrier for poor columnists (though not a very high one); but there'll probably be both free and pay services, with the pay services touting their independence, much as Consumer Reports and Ms. magazine-which don't accept advertising-do today. ${ }^{80}$

Books: In the book market, reviewers will play an even more critical role than they do today. Moreover, as with music, their recommendations will have more influence because they'll be easily available when the customer is buying the book. Electronic bookstores will let customers select only those books that were professionally reviewed, or books reviewed by particular reviewers (or reviewing businesses)-for instance, "new Science Fiction books that got positive reviews from reviewer $\mathrm{X}, \mathrm{Y}$, or $\mathrm{Z}$."

A writer will, instead of sending a manuscript to a publisher, send it to several reviewing services specializing in the field. Most reviewing services probably won't write full-length reviews; instead, they'll give the book a grade and maybe a one-paragraph summary and critique for the good ones. They might also compare the book to others by well-established authors (e.g., "people who like Larry McMurtry would probably like this one").

The services might charge the author for their efforts. Rates would start at a minimum that compensates for the reviewer's time-perhaps as little as a few hundred dollars-and would rise as the service becomes more and more popular and can thus charge extra for its name.

In a sense the reviewing market will reinvent part of today's publishing business and lead to some of the costs associated with it. Publishers perform an important screening function, which someone will still have to perform. Publishers also perform an important editing function, and there may well be

80. Doug Stewart, To Buy or Not To Buy, That Is the Question at Consumer Reports, SMrrHSONIAN, Sept. 1993, at 34, 36 (Consumer Reports); Lesley White, Feminism with No Ad-ditives, SUNDAY TIMES (London), Nov. 22, 1992, § 5, at I (Ms.); see also Cook's Magazine Is Back on Shelves, ORLANDo SENTINEL, June 24, 1993, at H6 (noting that Cook's Illustrated magazine "takes no advertising, [which] allows the staff to honestly rate and compare products"). 
editing services or freelance editors, who'll ask for either a fee or a royalty (which may not be possible for books that seem unlikely to succeed).

Thus, there'll still be organizations with the power to sink a book-here, reviewers rather than publishers-and there'll still be up-front costs-reviewing and editing fees rather than printing costs. But the costs will be much lower, and the reviewers will be more diverse, will represent more tastes, and will be better able to serve niche markets.

\section{Video (TV and Movies)}

"[T]hough the perceived defects of [television] are many ... they can be more or less subsumed in two words: vast wasteland." 81 Newton Minow, then chairman of the FCC, coined this pejorative in 1961, and it has (justly) stuck.

But if your local bookstore let you buy, at any given hour, only five books-each chosen for maximum appeal to 250 million people-you'd think of publishing as a vast wasteland, too. This would be true even if the store had fifty books, or maybe even 500 books to match the touted 500-channel cable system of the future. There'd be a greater chance that you'd get what you want, ${ }^{82}$ but still you'd often be dissatisfied. ${ }^{83}$

The problem with TV isn't lack of material. Plenty of excellent television has been created in the medium's almost fifty years. Add to that the many great movies that have been made, and there's enough for each of us to watch for hours every day and still only get the stuff we enjoy.

The problem is that broadcasting can't get you what you want when you want it. It can only get you what millions of people prefer, ${ }^{84}$ and it can only give it to you at the time chosen by the broadcaster, not the time chosen by you. Five hundred channels may help, because they may make room for material that appeals to only, say, a few hundred thousand people; but that will still be inadequate. ${ }^{85}$

What people would like, I believe, is to choose from home-at any time convenient to them-any TV show or movie they want, just as they choose a book in a bookstore, only more conveniently and less expensively (or even free, since the medium might still be advertiser-supported). ${ }^{86}$ Some people

81. Thomas G. Krattenmaker \& LuCas A. Powe, Jr., Regulating broadcast Programming 297 (1994).

82. In fact, with the advent of new channels such as CNN. CSPAN. the Discovery Channel. Nickelodeon, and so on, the "vast wasteland" critique of TV is less apt, too.

83. See generally George Gilder, Breaking the Box, NAT'L REV., Aug. 15, 1994, at 37 (recounung fears over increased customer choice).

84. The average major network-ABC. CBS, and NBC-audience in 1992 was 3 to 4 million per network in the mornings, 8 to 12 million in prime time, and 2.5 to 5 million in late night (11 p.m. to I a.m.). THE LEO BURNETT WORLDWIDE ADVERTISING AND MEDIA FACT BOOK 489 (1994).

85. See Mitchell Kapor, Where Is the Digital Highway Really Heading?: The Case for a Jeffersonian Information Policy. WIRED, July/Aug. 1993, at 53, 59, 94.

86. See Diane Francis, Fibre Optics Leapfrogs the 500 Channels. Fis. Post. July 19. 1994, at 11. 
might still want someone else to decide; they might, for instance, ask for a random comedy, or a random comedy praised by a given reviewer. They might even ask for the latest episode of a particular new show, just as they do on TV today, though at a time that's convenient for them. But they'll be the ones who choose, or choose to leave the choice to someone else.

This, of course, is "video-on-demand," which is already being tested-in a primitive form-in various markets. ${ }^{87}$ Many current video-on-demand proposals have gotten a skeptical market response. But the barriers all seem to me to be a function of current technology-the degree to which today's homes are properly wired (or fibered) for this service, the current costs of the equipment, and so on. The question, I think, is only whether video-on-demand will start arriving now or in several years.

Effect on What Will Be Available: As with the other media, this customization will give people access to much more diverse material. Today, to be broadcast on TV, new programs must have an expected audience of millions. To justify access to the scarce shelf space available in video stores, videotapes also need a large market. Lots of good stuff that doesn't appeal to a large enough audience never makes its way to the TV stations or video stores.

The new system should also increase the amount of new material being made. The cost of producing high-quality, high-production-values entertainment-from $\$ 500,000$ to over $\$ 1$ million per hour ${ }^{88}$-will slow down this diversification. So long as production costs remain high, each new program

[F]ibre optics leapfrogs beyond the 500-channel universe, satellite dishes, wireless systems and eventually newspapers because it is a two-way system. Instead of being dependent upon a network's schedule, producer's priorities or editor's choices, consumers can pick and choose what goes on their screens just as handily as they use their telephones. ...

$\ldots$...

The information highway will be an electronic version of the book business where consumers select from tens of thousands of choices for a variety of reasons: referrals, cover designs, advertisements, word-of-mouth suggestions, publicity stunts, best-sellers' lists or review endorsements.

Id. (paraphrasing Bill Gates of Microsoft).

87. See, e.g., Ted Bunker, The Multimedia Infotainment I-Way, LAN MAG., Oct. 1994, at S24; David Lieberman, Premiere of Video on Demand, USA TODAY, Oct. 12, 1994, at IB. Some of the early tests sound like something out of The Flintstones: When a request for a particular movie comes in, a person at the central station goes to a shelf, pulls out a videocassette, and inserts it into a VCR that then feeds the signal to the customer's TV. Id. at 2B. Obviously, this is only happening because it's a pilot project; a working system must be able to do all this automatically, and devices for implementing this have already been created. Bunker, supra, at \$24.

88. John Dempsey, Siegel Unveils First-Run Sitcom, VARIETY, Nov. 14, 1994, at 62 (noting that proposed new sitcom called Beverly Hills Beach Club will cost $\$ 225,000$ per half-hour); Tom Feran, "Make It So" "Generation" Ready for Final TV Journey, CLEV. PLAIN DEALER, May 21, 1994, at IF (noting that Star Trek: The Next Generation costs over $\$ 1.6$ million per hour); Ann Hodges, Spelling Scores on All the Networks, Hous. CHRON., Aug. 25, 1994, at 4 (noting that Spelling's new show, Robin's Hoods, has budget of \$1 million per hour); TV Execs Wrangle with FCC over "Educational" Label for Kids Shows, MEM. COM. APPEAL, June 29, 1994, at A4 (noting that PBS's Where in the World Is Carmen Sandiego? and Ghostwriter cost $\$ 390,000$ per half-hour). 
will still have to appeal to many people. ${ }^{89}$ Still, it will probably need less of an audience than it does today, when producers face both high production costs and limited distribution channels. Moreover, some video programming-talk shows, talking heads shows such as the McLaughlin Group, stand-up comedy. and some kinds of sporting events-costs relatively little to produce. ${ }^{90}$ Production of these shows ought to mushroom.

\section{SOCIAL CONSEQUENCES}

\section{A. Democratization and Diversification}

The new technologies I outlined above will, I believe, both democratize the information marketplace-make it more accessible to comparatively poor speakers as well as rich ones-and diversify it. Of course, the power to make one's speech globally available isn't the power to make it globally heard. One still has to get people to listen, through advertising, word of mouth, good reviews, or other devices. Advertising will still cost money, and well-funded bands or columnists or newsletters will still attract more readers than poorer ones will.

Nonetheless, while advertising is obviously useful, it's not strictly necessary; many products are sold today largely through word of mouth or reviews (especially when one considers radio as the reviewing medium that it is). Wealth will certainly remain relevant in the new information structure, but it will be a good deal less relevant than it is today.

Likewise, a greater diversity of available speech need not lead to diversification of what is actually consumed. It's possible that even after the coming of the infobahn, most people will still consume largely what they do today. But at least those people whose tastes differ from the majority's will be served. They might, of course, continue to complain about the majority's bad taste; but that's something no technology can do much about.

89. In 1992, advertisers paid from $\$ 2.40$ (CBS in the moming) to $\$ 9.23$ (ABC pnme tume) per thousand viewers for a 30-second spot. LEO BURNETT, supra nole 84. al 489. Assuming aboul 16 commercial minutes per hour, that translates into a budget of $\$ 75,000$ to almost $\$ 300.000$ per million viewers for an hour-long program. Note, however, that these people needn't all be watching at once. A program that today attracts 500,000 viewers for each of its 26 regular-season episodes and 500,000 for each of its reruns really has a viewership of $1,000,000$ per episode.

90. See, e.g., Jim Bessman, "Austin City Limits" Hits Milestone, BILboArd, Oct. 22, 1994, at 14 (describing cost as $\$ 700,000$ for season of 13 half-hours of country music concent show): Dan St. Ledger. Let's Put On a Show, Bus. DATELINE, Apr. 25, 1993, at I (deseribing cost of $\$ 40.000$ per episode for reality-based TV show); Debbi Snook, Inquiring TV Host. CLEV. PLAIN DExleR. Jan. 30. 1994, at IH (noting that relatively successful PBS nature show costs $\$ 65,000$ per season); Diane Turbide, Handyman's Special, MACLEAN's, Mar. 28, 1994, at 61 (noting cost of successful Canadian sttcom as \$70.000 per halfhour). 


\section{B. Shift of Control from the Intermediaries and What It Will Mean}

The trends I've described have one thing in common: They tend to shift control from intermediaries-record labels, radio and TV station owners, newspaper, magazine, and book publishers-to speakers and listeners. The relatively low cost of electronic distribution gives speakers more control over what is said: A speaker need no longer satisfy the intermediaries before being allowed to speak. The relatively low cost of personalized electronic distribution gives more control over what is heard to listeners; a listener may select his own mix of music and information, rather than taking what the intermediaries give him.

\section{Shift of Control to Listeners}

Ease of Getting More Information: The shift of control to listeners will, I think, make people better informed about the things in which they're interested. Say I want to read science stories, news about Eastern Europe, and opinions about the crime problem. The newspaper today gives me only as many stories on these topics as a typical reader might want to see. But I want more!

With the new technology, I'll be able to get as many of these stories as I want, either through receiving short newsletters (which will be cheap and easy to subscribe to), or through configuring for myself the mix of the stories in my morning paper. I may even be able to get important source material, such as the complete text of a speech, or a document, or an interview. Such material rarely gets printed in its entirety, because space and the patience of most readers are limited. But it can easily be made available electronically to those who want it. ${ }^{11}$

Ease of Being Closed-Minded: On the other hand, part of the value of the mass media is that they expose readers to topics and viewpoints the readers didn't select. A reader who thinks he doesn't care about science might come across a science story on the front page and find it interesting. A liberal reader may stumble across a conservative column in his daily paper and be persuaded by it. Yet the reader might not have subscribed to either story if he'd had the choice.

Of course, with the new system, people who want a variety of topics or views will easily be able to get them. Wise readers will probably request some general news for their mix, rather than just saying "give me international news, law, and science, and nothing else." Conservatives could subscribe to well-

91. See Michael Crichton, The Mediasaurus: Today's Mass Media Is Tomorrow's Fossil Fuel, WIRED, Sept.JOct. 1993, at 56, 58. Electronic versions of daily newspapers have already begun to includo "unpublished wire stories or background information for users who want to pursue a topic." Everett, supra note 47 , at 14 . 
regarded liberals, and vice versa. Some columnists will team up with others to produce two-sides-of-the-issue columns, much like the Column Left and Column Right in some newspapers today, or the TV show Crossfire. The new system may provide more multisided presentations than exist today (just because there'll generally be more options).

Many people, though, might not want a variety of topics, or especially a variety of views. Most of us to some extent prefer to listen to people with whom we agree. Often we won't even read opposing views in a newspaper that we've already bought; and we're especially unlikely to pay money-even small sums-for opinions with which we know we disagree. ${ }^{92}$ There are exceptions, but there's reason to fear that this sort of behavior is the rule.

Every reader, of course, has a right to be closed-minded; and people are already plenty closed-minded today, so the new technologies might not make a big difference in this respect. But they may marginally increase the degree to which people shield themselves from topics and opinions they expect to dislike.

Common Culture: Another part of the value of the mass media is that they give viewers a shared base of information. Every evening millions of people watch network news; every week they watch more or less the same TV shows. When they talk about events with friends or coworkers, they at least have a starting point for discussion.

But as the sources of information and entertainment become less generic and more custom-tailored, people may lose some of this common ground. They may find themselves having fewer shared cultural referents, and less common knowledge about current events, even if they have more knowledge about the events that interest them most. ${ }^{93}$ People who read the Democratic Party's organ and people who read the Libertarian Party's organ might have a hard time even speaking the same language about the issues.

Again, those who want to share common ground with their peers may choose to continue listening to Top 40 , or watch news shows that aim for a

92. One recent article, for instance, criticized the "fragmented, treacherous and completely foreign communications landscape" created by "cable and interactive television, remote control, VCRs, E-Mail and faxes," in which people want their news "from like-minded people, and stated in thetr own terms." This. the writer argues, leads people to "often choos[e] information delivered by demagogues appealing to fear. anxiety and prejudice through heated thetoric and distortion." Michael McKeon. Fragmenting of the News. WASH. POST, May 11, 1994, at A21. The author may be overstating things, but l think there's something to what he says.

93. See Dennis Palumbo, Perspective on Interactive Media: 500 Channels, Programmed Luves, L.A. TIMES, July 25,1994 , at B7.

[W] all have a shared history based on the TV pictures of the past years common to all Americans. A national memory shadowed by the same video images of Lucille Ball and Edward R. Murrow, the moon landing and the Mod Squad. Melrase Place and the nightmare-1n-slowmotion that was Dallas in ' 63 .

With the advent of the new technologies, this shared history is threatened. If we all control our screens, if we can program what we wateh and when for the sake of convenience, we lose this common experience in our culture.

Id. As with the commentary in the footnote above. this may be hyperbole, but with a gran of truth. 
well-rounded, mainstream view of the world. But many people won't do this. It's hardly likely that American society will fall apart because of this, but it's at least possible that more diversity of sources might mean less common ground and less social cohesion. ${ }^{94}$

\section{Shift of Control to Speakers: The Decline of Private Speech Regulations}

While American government agencies generally don't regulate speech, private parties do. Publishers sometimes refuse to publish material they disagree with. Private groups sometimes pressure publishers to drop certain material. And even the viewpoint-neutral reluctance of publishers to accept work that appeals to too few consumers has the effect of shutting out political fringe groups on all sides of the spectrum.

The shift of control from publishers to speakers will greatly weaken these private speech regulations. When speech comes straight from the speaker to the listener, there's no one in between to regulate the speech, and no one for various groups to pressure if they think the speech is reprehensible. Threats of boycotts may work against diversified companies that sell information to many markets-someone can tell, say, Time Warner Records "If you carry Ice-T's Cop Killer, I won't buy other Time Warner material." But telling Ice-T "If you keep singing Cop Killer, I won't buy your other material" probably won't work; people who say this probably wouldn't buy his music anyway.

There's no consensus today about whether such private regulations are proper. Some consider them almost as dangerous as government censorship; others argue that private pressure on speakers is legitimate, sometimes even laudable. ${ }^{95}$ But regardless of one's normative judgment on this, the new

94. This is analogous to the argument that has sometimes been made about private schools, which give parents more control over their children's upbringing, but are thought by some to threaten the common culture. Peter Schrag, Kiss Our Melting-Pot Heritage Goodbye, S.D. UNION-TRIB., July 15, 1993, at B13; cf. Meyer v. Nebraska, 262 U.S. 390, 402 (1923) (discussing argument that ban on teaching forcign languages would "foster a homogeneous people with American ideals prepared readily to understand current discussions of civic matters").

95. Compare Greg Kot, Chilling Silence, CHI. TrIB., Dec. 27, 1992, \& 13, at 12 (criticizing apparent willingness of Time Warner Records to pressure Ice-T to drop song Cop Killer from his album) with Jonathan Alter, Let's Stop Crying Wolf on Censorship, NEwSwEEK, Nov. 29, 1993, at 67 (praising such private speech regulations as sound journalistic judgment); compare McCalden v. California Library Ass'n, 955 F.2d 1214 (9th Cir. 1992) (concluding that private groups' actions that pressured another group not to provide forum for Holocaust revisionists could be tortious) with id. at 1226-31 (Kozinski, J., dissenting from denial of rehearing en banc) (concluding that such pressure was itself protected by the First Amendment). See Elizabeth Venant, An "American Psycho" Drama, L.A. TIMEs, Dec. 11, 1990, at E1 (describing different views of Simon \& Schuster's refusal to publish Bret Easton Ellis' American Psycho because of its graphic depictions of dismemberment of women, and of threatened NOW boycott of book's next publisher); see also Brenda Herrmann, Radio Tuning Out Gangsta Rap, CHI. TRIB., Jan. 18, 1994, at $\mathrm{Cl}$ (discussing some radio stations' refusal to play violent or misogynistic rap songs); Stephanie Lynam. NOW Wants Media To Cull Images Degrading Women, NEW ORLEANS TIMES-PICAYUNE, Nov. 3, 1994, at $13 \mathrm{Hl}$ (discussing proposals for boycotts of video stores that carry some slasher movies). 
information media will make it much harder for such private speech regulation, good or bad, to take place.

Of course, there'll still be some intermediaries. Though the power of publishers will wane, the equivalents of the music stores and bookstores-the music databases, and the computer systems that people access to subscribe to opinion columns, to buy books, or to get video-on-demand-will remain. They could refuse to carry certain kinds of speech, and various groups could pressure them into doing this.

But such a refusal will probably have a limited effect on the speech that's being rejected. Each infobahn-connected home will be able to access every computer service in the nation. If one service refuses to carry, say, gangsta-rap music, others can instantly take advantage of the resulting market.

Moreover, starting a new nationwide electronic service should be comparatively cheap, certainly cheaper than starting a nationwide chain of bookstores or music stores. Today, it's conceivable that all the major stores in an area might refuse to carry a certain product. But even if all the mainstream computer services reject a particular genre, other services-say, an all-gangstarap service, or even a service specializing in materials that others don't carry-could easily spring up. The private speech regulations will remain only where there must be intermediaries who select what gets distributed, for instance in newspapers, whose editors will still control who writes for them. ${ }^{\%}$

Another form of speech regulation I alluded to above-regulation by poverty and unpopularity-will also become much less potent. Many extremist groups have relatively little ability to speak out because they don't have enough of a base to fund their speech. At least one $\mathrm{KKK}$ chapter, for instance, is dormant largely because it's broke. ${ }^{97}$ Cheap electronic distribution might mean that not only the ACLU or NRA newsletters, but also the KKK and Communist Party newsletters, could be sent to millions of subscribers. ${ }^{98}$ One would hope these fringe groups would find few people willing to listen, but their voices would be amplified along with the voices of worthier organizations.

Finally, the new media might affect one more sort of speech regulation: self-regulation for accuracy. It's generally assumed that intermediaries-publishers, editors, and broadcasters-help make sure the

96. See James Warren, Andy Rooney Suspended, But Dentes Racist Comment. Cill. TRlB., Feb. 9, 1990. $\S 1$, at 3 (describing CBS's suspension of 60 Minutes commentator Andy Rooney for allegedly makıng racist comment); Jerry Berger, Kennedy Cries Reagan Civil Rights Policies. UPI. Jan. 18, 1988, avallable in LEXIS, News Library, UPI File (describing CBS's firing of Jimmy "The Greek" Snyder on simular grounds).

97. See Jerry Schwartz, Klan Group Forced To Disband in Allanta Law'sut,. Reuters, May 20, 1993, available in LEXIS, News Library, Reuna File.

98. See, e.g., Missouri Knights of the KKK v. Kansas City. 723 F. Supp. 1347 (W.D. Mo. 1989) (describing KKK's ultimately successful attempts to get time on local cable system's public access channel). 
things we read and hear are actually true. They might, for instance, fact-check articles, or refuse to work with writers who are known to be unreliable.

But when speakers can communicate to the public directly, it's possible their speech will be less trustworthy: They might not be willing to hire fact checkers, or might not be influenced enough by professional journalistic norms, or might not care enough about their long-term reputation for accuracy. Talk radio, for instance, has been criticized for being unreliable in large part because of how democratic and spontaneous it is. ${ }^{99}$

It's not clear, though, what the magnitude of the greater inaccuracy would be. The new technologies will give some untrustworthy speakers a forum that responsible editors would deny them, and some people will end up misinformed by these speakers. But the majority of new speakers may be no worse than most media of today. Many leading publishers actually don't employ fact checkers; ${ }^{100}$ and while today's media aren't notorious for intentional falsehoods, misunderstandings and misreporting seem quite common-consider how often we all find errors in newspaper articles about subjects we know well.

At worst, the new technologies may supplement some fairly unreliable publications with other, perhaps more unreliable, ones. At best, they might allow the publication of more trustworthy materials-for instance, science news publications put out by specialists, rather than generalist journalists-that couldn't be printed before.

\section{Poor Consumers}

When I say the new technologies will shift power to listeners, I mean of course listeners who can afford the new technologies. But what about

99. See, e.g., Nat Hentoff, New FCC Head Frets Sometimes over Free Speech, RockY MouNTAIN NEws, Nov. 28, 1994, at 42A (describing complaints by FCC Chairman Reed Hundt and outgoing Speaker of the House Thomas Foley); Claudia Puig, FCC Chief Wants Talk Radio Shows To Deal in 'True Facts', L.A. TIMES, Oct. 14, 1994, at D2, D2-DS (same); Chuck Raasch, Talk May Be Cheap, But It's Big on Radio, GANNETT NEWS SERV., Sept. 25, 1994, available in LEXIS, News Library, GNS File (describing complaints that talk radio is rife with rumor and misinformation); Howard Kurtz, Radio Daze, WASH. POST, Oct. 24, 1994, at B1 (calling talk-radio show hosts angry "rumor-mongers" who eschew maintenance of "appearance of journalistic balance").

A recent science-fiction novel, VERNOR VINGE, A FIRE UPON THE DEEP (1992), has a memorable line, a sort of proverb of the future. Referring to an interstellar communications network seemingly modeled on today's Internet, the characters say: "It's not called the Net of a Million Lies for nothing." Id. at 228, 309, 431.

100. See Steve Weinberg, The Kitty Kelley Syndrome; Why You Can't Always Trust What You Read in Books, ColuM. JouRNALISM REV., July-Aug. 1991, at 36, 37 (stating that "few nonfiction books arc checked for accuracy" and that "[a]s a result, inaccuracies abound"); Richard Blow \& Ari Posner, Are You Completely Bald? Adventures in Fact Checking. NEw REPUBLIC, Sept. 26, 1988, at 23, 23 (describing how The New Republic has no fact checkers, "partly for deadline reasons, partly for financial reasons, and partly because of philosophical doubts about whether devoting limited resources to catching the kinds of things fact checking catches is the best way to serve the larger cause of printing the truth") (confirmed by author's personal conversation with magazine's editorial department on Dec. 6, 1994). 
consumers who can't buy a computer, a digital recorder, a printer, a cbook, and an infobahn hookup?

Music: Poor consumers should benefit from electronic music delivery. Even if they can't afford the hardware, they should be able to buy their music from public vending machines. ${ }^{101}$ While it may cost more to buy from these machines than it would to buy from home, it should still cost less than it does now. Of course consumers will still need devices that play these recordings, but there's no reason to think they'll end up costing more than about what $C D$ players do now.

Short Opinion Articles: Opinion articles may be different. Home delivery of selected opinion articles will work because subscribing to the articles and getting them each morning is easy. If your favorite columns are there on your printer when you wake up, you'll read them. But if you must go every day (or even every week) to a public terminal, select what you want, and wait for it to print, the result will be much less useful to you. And the cost of such public access may be a good deal higher as a proportion of the normal price than it would be for music.

On the other hand, this system might not be much worse for poor people than the existing one. People who can't afford the needed computer hardware might also be unable to afford a $\$ 200$-per-year subscription to The Los Angeles Times. And with over eighty percent of all U.S. households owning VCRs, ${ }^{102}$ the affordability of home electronics to even the not-so-rich shouldn't be underestimated.

Books, Magazines, and Newspapers: Books, magazines, and newspapers are a still different matter. It's easy to imagine public terminals that download such materials-especially books and magazines-onto your cbook. ${ }^{103}$ They won't be any harder to use than a bookstore is today, and the text itself will be cheaper than it is in a bookstore. The cbook itself may be a sizable upfront investment, however, and it may be particularly hard to afford for parents of small children, because the children may be likely to break it or lose it.

The new technology may also require a rethinking of a substantial subsidy the government now gives readers: public libraries. Even if electronically distributed books cost much less than books do today, many people would still prefer to borrow the books for free.

How would libraries be able to lend electronically distributed books? Under the model I described above, a "book" will no longer be a tangible item, not even, say, a floppy disk. To buy a book, you'd just download it onto your

101. See supra text accompanying note 33.

102. David Lieberman, Premiere of Video on Demand, USA TODAY. Oct. 12, 1994, at IB, 2 B.

103. Cf. World Wide Web Draws Interest. TAmpA TruB., Nov. 21, 1994, Business \& Finance Secuon. at 10 (describing U.S. Postal Service plans to put Internet kiosks in its buildings so public can aceess various government agencies). 
cbook. If a library, though, downloads the book for you, you haven't borrowed the book-you've gotten it permanently, a clear copyright violation.

But even if a library tries to better emulate the economic effects of conventional library lending-embeds a three-week expiration date in the electronic data, ${ }^{104}$ and refuses to lend the same book to more than one customer at a time-this would still violate copyright. Copying electronic data onto a computer, even in a way that has the same market effect as lending of paper books by today's libraries, is a copy and almost certainly an infringement. ${ }^{105}$ While Congress can change this scheme, copyright owners may lobby hard against it. They already look with envy at some other countries' copyright laws, which provide for a royalty to be paid every time a book is lent. ${ }^{106}$

On the other hand, the new technology may greatly decrease many of the costs of running libraries-shelf space, reshelving, and so on. Some accommodation might be reached in which authors' organizations agree to some blanket licensing agreement, ${ }^{107}$ or to changes in the copyright law. The money saved by libraries on paper books could be spent to compensate authors on a per-loan basis. ${ }^{108}$

Used bookstores, another place where people today can get books cheaply, will also run into problems in the cbook age. It's not copyright infringement to resell a paper book, ${ }^{109}$ but it almost certainly would be infringement to copy a book from your cbook disk to someone else's, even if you delete the original. ${ }^{110}$

Changing the law to allow copy-and-delete transactions-on the theory that they're just like selling a tangible copy-may be unfair to authors. Used book sales today have a limited effect on new book sales, because used books are less desirable than new books (they're often worn and torn), and because used bookstores often don't have large or well-arranged stocks. But if used electronic books could be sold, they could substantially undercut sales of new books: Used electronic books are as good as new ones; national electronic used

104. Expiration dates are feasible, assuming some cooperation from the cbook software. Some users might be able to avoid them by somehow tampering with the software, and underground expiration date cracking programs might become widely available. Still, it should be possible to have an expiration feature that's enforceable against the great majority of users.

105. See 17 U.S.C. $\$ 106$ (1988) (giving owner exclusive right to reproduce copyrighted work); MAI Sys. Corp. v. Peak Computer, Inc., 991 F.2d 511, 518 (9th Cir. 1993) (holding that "loading of copyrighted software into [computer memory] creates a 'copy' of that software in violation of the Copyright Act").

106. Jennifer M. Schneck, Note, Closing the Book on the Public Lending Right, 63 N.Y.U. L. REV. $878,880-81$ (1988).

107. Such as the ASCAP or BMI licensing agreements that are commonly used to license the right to perform musical compositions.

108. Cf. Audio Home Recording Act of 1992, 17 U.S.C. $\S \S 1001-1010$ (Supp. V 1993) (embodying similar compromise, in which owners of music copyrights are compensated from sales of DAT recorders and blank DATs, and in exchange individuals are allowed to copy music for noncommercial purposes).

109. 17 U.S.C. \& 109(a) (Supp. V 1993).

110. See supra note 105 . 
bookstores could have a huge selection; and obviously they wouldn't need a lot of clerks to keep the books in sorted order.

Authors could legitimately complain that allowing sales of used electronic books will cost them much more than allowing sales of used paper books does today. " A legislative or contractual compromise could be reached-for instance, a royalty could be imposed on each resale of a used electronic book-but it might not be easy.

Video-on-Demand: Finally, video-on-demand probably will not, once it's a mature technology, be particularly burdensome even for relatively poor people. While it might require new TV equipment, and again the infobahn connection, there's no reason to think it will eventually cost much more than a TV, a VCR, or a telephone-staples of American homes-do today. This is especially true because video-on-demand is as good an advertising medium as commercial TV.

\section{What Will Happen to Advertising (Both Commercial and Political)}

The new technologies will have at least three significant effects on advertising:

First, it will be easier and cheaper to have advertising-free media. Consumers generally don't like commercials on radio and TV, because (unlike in newspapers) the ads interrupt the program content. Some consumers dislike commercials enough that they would be willing to pay extra for advertisingfree media, as they now do for some cable movie channels.

Other consumers would prefer to have free (or cheaper) entertainment, and would be willing to sit through the commercials to get it. Still, as the costs of providing services-such as custom-mix cable radio-fall, the amount of advertising on free services will fall, too, as services compete with one another based on how few commercials they have. ${ }^{112}$

Advertisements in newspapers and magazines are less intrusive, so there'll be less pressure to reduce their quantity. Some publications might refuse ads to prove their independence from outside pressure, ${ }^{113}$ but this seems unlikely to become common.

Second, newspapers will lose a vast amount of classified ad revenue. This revenue accounted for forty percent of total newspaper ad revenue in the late

111. They've made exactly this complaint about sales of used CDs. In Lichtman. Songwriting Community Speaks Out on Used CDs, BiLLBOARD, Sept. 4. 1993, at 16. In fact. CD distnbutors tned to pressure stores not to sell used CDs, steps that led to a restraint of trade lawsuit and ulumately a settlement. Dispute Between Music Companies and Record Store Owhers over Sale of Used CD's is Settled. ENT. 1. REP., Apr. 1994, at 26.

112. This already happens with broadcast radio stations. Sec. e.g. Pete Schulberg. Portland's Radto Stations: On a Roll, OREGONIAN, June 12, 1994, at Fl.

113. See sources cited supra note 80 (describing how Consumer Reports and M/s. do this today). 
1980 's; ${ }^{114}$ one commentator projects it will reach sixty percent by $2000 .{ }^{115}$ But paper classifieds are far inferior, for both buyers and sellers, to electronic classifieds that are untied to any newspaper.

A database of, say, all apartments for rent in the city would be much easier to search through than a newspaper classified section: From a publicaccess terminal, ${ }^{116}$ the renter could ask for an instant list of all the onebedroom apartments renting for less than $\$ 850$ per month within three miles of UCLA, perhaps plus apartments that are a bit cheaper but a bit further, or more expensive but closer. ${ }^{117}$ The list should be more complete, because the information will be easier and cheaper to post. And the list should be timelier-the information will become available as soon as the landlord posts it, and can be removed as soon as the apartment is rented. Electronic classifieds are better on all counts than paper ones, and newspapers will have to adjust to a huge revenue loss when the paper classifieds stop coming in. ${ }^{118}$ The loss of classified revenues, coupled with the cost savings and opportunities for extra profits from electronic distribution, should help push newspaper publishers into going electronic.

Third, individualization of the media will let advertisers target customers better than ever before. Instead of one newspaper with ads aimed at several hundred thousand people, each electronically delivered newspaper will have ads calculated to fit the particular subscriber's profile-age, sex, and whatever other information the newspaper gets at subscription time, or can deduce from the mix of stories he's ordered. ${ }^{119}$ The same would be true for the other media.

The greater ease of targeting ads may also change the way political campaigns reach voters. This is already happening: In one political consultant's words, "if you want to talk to women, buy 'Sisters' Saturday night; men, you buy ESPN; seniors, 'Murder She Wrote'; everyone, [the local football team]

114. Hanna Liebman, $A$ Welcome Change for a Troubled Industry Predicted in New Report on Newspapers, MEDIAWEEK, Nov. 29, 1993, at 5.

115. Dorothy Giobbe, The Future of Print Classifieds, EDIroR \& PUBLisHeR, July 16, 1994, at 24.

116. See supra note 103.

117. See Vic Sussman, News of the Wired, U.S. NEWS \& WorLD REP., May 16, 1994, at 60, 62.

118. See Aaron Zitner, Globe To Offer New On-line Services, Boston Globe, Dec. 7, 1994, at 49. 57 (stating that "publishers are concerned that competitors will cut into their print revenues by putting real estate, help wanted and other advertisements on-line" and that "[c]lassified ads, which account for half of all Globe advertising revenues, are considered particularly vulnerable"). Newspapers can, of course, enter the classified market themselves. See Giobbe, supra note 115, at 24. But the newspapers won't have any substantial edge over other service providers in this field. And even if a newspaper comes up with a fabulously profitable electronic classified service, the stockholders will probably be hesitant to use this service to subsidize a money-losing print operation.

119. See Gilder, supra note 58, at 25; Michael Schrage, Is Advertising Finally Dead?, WIRED, Fcb. 1994, at 71, 73 (describing advertising that is both "narrowcast[] and interactiv[e]"). This might raise complicated privacy issues (which are beyond the scope of this Essay). See Video Act of 1988, 18 U.S.C. $\S 2710$ (restricting information video stores can disclose about their customers); Cable Act of 1984, 47 U.S.C. § 551 (1988) (restricting information cable operators can collect or disclose about their customers). 
or "60 Minutes." "120 Another consultant points out that "yuppies, paricularly working mothers ... don't watch TV regularly, but do sit in traffic jamswhich makes radio a good buy."121

When targeting becomes even easier, candidates can speak even more directly to particular voters, with ads specially targeted at those people. This would give voters more information about the issues that matter to them; and voters who want deeper treatment of the issues might get their wish, as campaigns try to avoid alienating them with shallower commercials.

On the other hand, targeted ads might in some ways be worse for the democratic process than mass ads are. The targeted ads might appeal more to parochial interests and prejudices and less to the common good; and candidates might be able to make arguments to small groups that they would rather not make to the public at large. ${ }^{122}$

These are, of course, only tentative guesses; still, it seems likely that the demassification ${ }^{123}$ of the mass media will substantially change the way both products and politicians are advertised. To the extent advertising is important to political campaigns, these changes ought to be considered.

\section{A FEW WORDS ABOUT THE NEW MEDIA AND THE FIRST AMENDMENT}

\section{A. Existing Flashpoints}

The proto-infobahn of today - the Internet, bulletin boards, and various commercial services - has already generated quite a few First Amendment controversies. Professor Anne Branscomb has ably summarized many of them in another Essay in this Symposium. ${ }^{124}$

Some of these may only be transplants of conventional questions into a new but essentially similar environment. For instance, there's already a lively

120. Susan Gilmore, Candidates Bet Big Bucks on Those T.V. Spots: Deep Analysis Behind 'Setnfeld' vs. ESPN, SEATTLE TIMES, Nov. 4, 1994, at Al, A15 (quoting political consultant Brett Bader).

121. Id. (paraphrasing consultant Frank Greer).

122. Of course, the candidate shouldn't create ads that would be too embarrassing if revealed to the public at large. For instance, in the 1990 Minnesota senatorial campaign, a letter was sent to the Jewish community on behalf of then Senator Rudy Boschwitz criticizing his opponent. Paul Wellstone, for marying a non-Jew and raising his children outside the faith; the strategy appears to have backfired when the ads got a lot of press. See, e.g. Chuck Raasch. Campaign Ads Gor Nastier as Election Goi Closer. GANNETT NEWS SERV., Nov. 8, 1990, available in LEXIS, News Library. GNS File.

123. The word "demassify"-which, I think, captures well what the new technologies will do to the media-was coined (or at least popularized) by Alvin and Heidi Toffler. See ALVIN TOFFER. THE THURD Wave 171-83 (1980); The "Future Shock" Man Sees More Drastic Changes Ahead: Interview with Alvin Toffler, Author, U.S. NEws \& WORLD REP., May 5, 1975, at 53, 54. See generally PROGRESS \& FREEDON FOUND., CyBERSPACE AND THE AMERICAN DREAM: A MAGNa CARTA FOR THE KNOWLEDGe AGe (1994); Alvin TOFfler \& Heidi TOfFler, Creating a New Civilization: The polmics of the third ivave (Progress \& Freedom Found. 1994).

124. Anne Wells Branscomb. Anonymin: Autonomy; and Accountabilin: Challenges to the First Amendment in Cyberspaces, 104 YALE LJ. 1639 (1995). 
debate about the propriety of regulating sexually harassing speech; ${ }^{125}$ harassing speech on electronic bulletin boards should just be a special case of this. The mens rea requirements imposed by the Supreme Court on libel actions may be adequate for protecting bulletin board operators from liability for messages whose contents they had no way of knowing. ${ }^{126}$ Likewise, the advent of electronic communications may change how child pornography is distributed, ${ }^{127}$ but I don't see how it would change the rules relating to child pornography.

Other conflicts, though, may well require changes to existing doctrine, because they reflect ways in which the new media genuinely differ from the old. The law of speech is premised on certain (often unspoken) assumptions about the way the speech market operates. If these assumptions aren't valid for new technologies, the law may have to evolve to reflect the changes.

Newspapers, for instance, are today held strictly liable for copyright infringement; ${ }^{128}$ part of the reason for this is that they have broad control over what they choose to print. ${ }^{129}$ When this assumption of control fails, as it does for electronic bulletin boards, strict liability may be inappropriate and perhaps even unconstitutional. ${ }^{130}$ The courts that developed the strict liability

125. Compare Letter from John E. Palomino, Regional Civil Rights Director for United States Department of Education, Office of Civil Rights, to Dr. Robert F. Agrella, President of Santa Rosa Junior College 6-7 (June 23, 1994) (on file with author) (urging college to institute speech code on grounds that harassing speech in particular academic setting was not constitutionally protected) with Dambrot v. Central Mich. Univ., 839 F. Supp. 477 (E.D. Mich. 1993) (striking down university's hostile environment harassment code as unconstitutionally overbroad); compare Suzanne Sangree, Title VIl Prohibitions Against Hostile Environment Sexual Harassment and the First Amendment: No Collision in Sight, 46 RuTOERS L.J. 461 (1995) (arguing workplace hostile environment harassment law is constitutional) with Kingsley R. Browne, Title VII as Censorship: Hostile-Environment Harassment and the First Amendment, 52 OHtO ST. L.J. 481 (1991) (arguing contrary) and Eugene Volokh, Comment, Freedom of Speech and Workplace Harassment, 39 UCLA L. REV. 1791 (1992) (taking intermediate position).

126. See Cubby, Inc. v. Compuserve Inc., 776 F. Supp. 135, 139 (S.D.N.Y. 1991) (holding that bulletin board operator can't be held liable for defamatory posting under established libel mens rea nules). Electronic distribution might still lead to some adjustments in the law: As the costs of allowing replies fall, laws that require a right of reply to false defamatory material might become more viable. See Edward $A$. Cavazos, Note, Computer Bulletin Board Systems and the Right of Reply, 12 REv. LITIO. 231 (1992).

127. See John C. Scheller, Comment, PC Peep Show: Computers, Privacy, and Child Pornography, 27 J. MARSHALL L. REV. 989 (1994).

128. Buck v. Jewell-La Salle Realty Co., 283 U.S. 191, 198-99 (1931) (holding that copyright infringement is strict liability tort); 3 MELVILLE B. NIMMER \& DAVID NIMMER, NIMMER ON COPYRIGIrT $\S 13.08$, at 13-264 \& n.2 (1994) [hereinafter NIMMER ON COPYRIGHT].

129. See Pinkham v. Sara Lee Corp., 983 F.2d 824, 829 (8th Cir. 1992); 3 NimMER ON COPYRIGIT, supra note $128, \S 13.08$, at $13-267$.

130. Cubby, 776 F. Supp. at 139; see Smith v. California, 361 U.S. 147 (1959) (holding that strict liability for unknowing sales of obscene literature is impermissible in criminal context); see also Manual Enter., Inc. v. Day, 370 U.S. 478 (1962) (suggesting same in context of civil penalties). As the Court put it in Manual Enterprises, deciding whether federal law let the Post Office bar a magazine carrying ads for obscene matter from the mails:

Since publishers cannot practicably be expected to investigate each of their advertisers, and since the economic consequences of an order barring even a single issue of a periodical from the mails might entail heavy financial sacrifice, a magazine publisher might refrain from accepting advertisements from those whose own materials could conceivably be decmed objectionable by the Post Office Department. This would deprive such materials, which might otherwise be entitled to constitutional protection, of a legitimate and recognized avenue of 
rule might not have consciously thought about this assumption, and it's certainly unlikely that they thought about it in a First Amendment context. ${ }^{131}$ In a world where this assumption was false, though, courts could well develop a different rule.

Likewise, as the economic constraints on sending tidal waves of unsolicited mail are removed, legal restrictions may have to take their place. Today such restrictions might be seen as unconstitutional, at least as to noncommercial speech. ${ }^{132}$ But if indeed e-mailing is next to free, then the assumption that the "short, though regular, journey from mail box to trash can" is "an acceptable burden, at least so far as the Constitution is concerned" may stop being reasonable. ${ }^{133}$ Similarly, in the obscenity context, the "community standards" test presumes that sellers know to which community they are selling. As computer networks make it possible for people to get obscenity without so much as supplying a mailing address, the very concept of local community standards may become obsolete. ${ }^{134}$ Still, all these seem like small changes, ones that don't cast into doubt the basic rules of the First Amendment: The general requirement of content neutrality, the exemption of certain kinds of speech from protection, the lower protection given to commercial speech, and so on. ${ }^{135}$

But if the discussion in Parts I and II is correct, the new technologies will change the speech market much more dramatically than we've seen so far. Today's First Amendment law evolved in a media world that had particular characteristics. A relatively few established outlets carried most of the speech that mattered. Extremist speakers had fairly little access to the public. The main news sources-TV programs and newspapers-provided a mix of ostensibly nonpartisan information about a variety of topics. The limited set of

access to the public.

Id. at 493. The analogy to copyright infringement liability seems strong. though not perfect. See also Edward M. Di Cato, Operator Liability Associated with Maintatning a Computer Bullestn Board. 4 SOFTWARE LJ. 147, 155-56 (1990) (advocating mens rea of gross negligence as minimum for holding system operators liable for copyright infringements done using their systems); $c f$. De Acosta v. Brown. 146 F.2d 408, 412 (2d Cir. 1944) (Hand, J., dissenting) (arguing that holding magazine publisher lable for infringement by contributing author "is likely to prove an appreciable and very undesirable burden upon the freedom of the press").

131. The Supreme Court has never considered this issue, and I'm unaware of any lower courts that have discussed it at any length.

132. Even noncommercial door-to-door soliciting - which is much more intrusive than unwanted mal or e-mail-is constitutionally protected. Martin v. City of Struthers, 319 U.S. 141 (1943).

133. Bolger v. Youngs Drug Prods. Corp., 463 U.S. 60 (1983) (intemal quotation marks omutled). This language was used in Bolger with regard to a content-based restrietion. assertedly justified by a desire to protect householders from offensive material. Still, the argument is founded on the perceived ease of discarding unwanted mail, regardless of the reason it's not wanted. If e-mailing is cheap enough that one's mailbox may get hundreds of messages a day, the burden of soring through them may become 100 great.

134. See I. Trotter Hardy, The Proper Legal Regime for "Cyberspoce". 55 U. PITT. L REV. 993. 1012-13 (1994).

135. See also David J. Goldstone. The Public Forum Doctrne in the Age of the Information Superhighway, 46 HASTings L.J. 335 (1995) (proposing changes to public-forum doctrine as to government-owned networks). 
sources gave people a more or less common base of information from which to argue. These underlying characteristics are, in my view, more significant than the ones discussed in the last few paragraphs. If they change, what consequences will this have for First Amendment law?

\section{B. A Rosy Future}

Let me begin my answer with the good news.

Existing First Amendment doctrine is founded on some rather idealized premises. "[T]he best test of truth is the power of the thought to get itself accepted in the competition of the market."136 "[T] he fitting remedy for evil counsels is good ones." 137 People who are offended by speech may "effectively avoid further bombardment of their sensibilities simply by averting their eyes." 138

These premises may often be true, but sometimes they simply aren't. Sometimes the supporters of a thought have millions of dollars, while opponents are too poor to compete effectively. Some markets are monopolized by one speaker, for instance a single cable system. ${ }^{139}$ Good counsels from poor speakers may often not be an adequate remedy for evil ones from richer, louder speakers. ${ }^{140}$ And Justice Stevens had a point: "To say that one may avoid further offense by turning off the radio when he hears indecent language is like saying that the remedy for an assault is to run away after the first blow." ${ }^{141}$ Unless offense is simply constitutionally irrelevant (in which case the possibility of averting one's eyes or ears shouldn't matter), once the words are heard the injury is complete.

The Court has heard these arguments. It has accepted that they may sometimes have merit. And yet it has generally-most notably in Turner Broadcasting System, Inc. v. FCC and Miami Herald v. Tornillo-refused to change the doctrine to accommodate them. ${ }^{142}$ It may have been right to

136. Abrams v. United States, 250 U.S. 616, 630 (1919) (Holmes, J., dissenting).

137. Whitney v. California, 274 U.S. 357, 375 (1927) (Brandeis, J., concurring).

138. Cohen v. California, 403 U.S. 15, 21 (1971).

139. See, e.g., Turner Broadcasting Sys., Inc. v. FCC, 114 S. Ct. 2445, 2468 (1994).

140. Cf. Miami Herald Publishing Co. v. Tornillo, 418 U.S. 241, 251 (1974).

141. FCC v. Pacifica Found., 438 U.S. $726,748-49$ (1978).

142. See Turner Broadcasting, 114 S. Ct. at 2458 ("[T] a speech market, without more, is not sufficient to shield a speech regulation from the First Amendment standards applicable to non-broadcast media."); id. at 2468 (acknowledging cable systems' "bottleneck monopoly power"); Miami Herald, 418 U.S. at 251, 254 (acknowledging that high cost of publishing newspaper "ha[s] made entry into the marketplace of ideas served by the print media almost impossible," but concluding that law requiring newspapers to carry replies to attacks on candidates was still barred by "the express provisions of the First Amendment and the judicial gloss on that Amendment developed over the years"); see also Buckley v. Valeo, 424 U.S. 1 (1976) (generally rejecting arguments that wealth inequalities justify government restrictions on some speakers aimed at benefiting others). But see Austin v. Michigan Chamber of Commerce, 494 U.S. 652, 660 (1990) (accepting, in limited context of corporate expenditures that support political candidates, speech restriction aimed at avoiding "corrosive and distorting effects of immense aggregations of wealth" on political process); Pacifica Found., 438 U.S. at 748-51 
refuse; it might, for instance, be too dangerous to let the government intervene when it thinks it has found "market failure,"143 or an inability to counterspeak, or a situation where the sting of offensive words is so great that averting one's eyes is no remedy. And even when the Court's assumptions are counterfactual, they might still be required because they represent "the theory of our Constitution"144-a basic principle that government must assume to be true even when it might not be. But it remains true that the Court has based its jurisprudence on an idealized view of the world, a view that doesn't quite correspond to the world in which we live.

What I've tried to suggest above is that this idealized world-where money is no barrier to speaking; where it's easy to avert eyes from offensive speech; where there's more than one newspaper in each town, and something other than a vast wasteland on TV-is much closer to the electronic media world of the future than it is to the print and broadcast media world of the present. If my predictions are right, the new technologies will make it much easier for all ideas, whether backed by the rich or the poor, to participate in the marketplace. Even if many individuals still can't afford to counterspeak effectively, there'll be many more organizations able to speak out on all sides of an issue. And when one's radio is no longer a dumb receiver but rather a computer capable of screening out whatever the listener wants removed, a householder really will be able to "avert his eyes"-and his children's eyes-from radio profanity (or TV nudity or what have you), rather than having to wait for the first blow. ${ }^{145}$

Copyright specialists are fond of suggesting that we operate in an electronic age under a copyright law created for a print age. It seems to me that during the print age, the Supreme Court created a First Amendment for the electronic age. The fictions the Court found necessary to embrace are turning, at least in part, into fact.

(accepting, in limited context of broadcasting, speech restriction aimed al avolding listener offense): Red Lion Broadcasting Co. v. FCC, 395 U.S. 367 (1969) (accepting. in limited context of broadcasting, burden on speech justified by concern about spectrum scarcity).

Zechariah Chafee's seminal First Amendment advocacy, in fact, has been charactenzed as consciously accepting a willful blindness about the flaws of the speech market: "The constitutional defense of free speech, [Chafee] declared, would implicitly pretend that the distribution of economic resources did not affect the system of freedom of expression." Mark A. Graber. Transforsisg FreE SPEECI 161 (1991)

143. See Turner Broadcasting, $114 \mathrm{~S}$. Ct. at 2480-81 ( $\mathrm{O}^{\circ}$ Connor, J., concurring in part and dissentung in part); Austin. 494 U.S. at 692 (Scalia, J., dissenting). See generally KRATTEvMAKER \& POWE, supra note 81 (asserting that government attempts to compensate for perceived market failures in broadcasung have done more harm than good).

144. Abrams v. United States, 250 U.S. 616. 630 (1919) (Holmes, J.. dissenung)

145. I haven't discussed this last point above, but it's well documented in other sources. See. e.g., Robert Brehl, Personal 'Genie' Will Cull Masses of Data for You. TORONTO STAR. Oct. 24. 1994. at B3 (describing "bozo filters," a primitive version of this): Leslie Miller. Prodigy Guides Its Users into Internet. USA TODAY, Oct. 20, 1994, at SD (same). 


\section{A Possible Dark Side}

But some of the other assumptions that the new technologies will upset may lead to more trouble. Missouri Knights of the KKK v. Kansas City ${ }^{146}$ tells a cautionary tale. In exchange for giving a franchise to a cable company, Kansas City demanded that the company provide a public-access channel. Everything went well until the Ku Klux Klan decided to put on its own show, which offended the city government so much that it authorized the cable system to shut the entire channel down.

A court ultimately overturned the city's action on First Amendment grounds, but the story shows what can happen when the assumptions underlying certain rules are changed. The city's willingness to provide a forum for the little guy, it turned out, was based (perhaps unconsciously) on the supposition that the little guys would either provide a public service or at worst be harmless eccentrics. When the assumption proved false, the consensus behind the rule evaporated.

As the new media arrive, they may likewise cause some popular sentiment for changes in the doctrine. Today, for instance, the First Amendment rules that give broad protection to extremist speakers-Klansmen, Communists, and the like-are relatively low-cost, because these groups are politically rather insignificant. Even without government regulation, they are in large measure silenced by lack of funds and by the disapproval of the media establishment. What will happen when the KKK becomes able to conveniently send its views to hundreds of thousands of supporters throughout the country, or create its own TV show that can be ordered from any infobahn-connected household? ${ }^{147}$

Likewise, the broad protection for false speech ${ }^{148}$ evolved in a time when the main suppliers of news and opinion were large, ostensibly nonpartisan, media organizations. Obviously these broadcasters and publishers weren't entirely reliable-they still lost some libel lawsuits even after New York Times v. Sullivan -but they were the sort of speakers that people could feel relatively comfortable with.

But with the emergence of talk radio as a powerful force, some have begun to grouse. Consider, for instance, a recent speech to the National Association of Broadcasters by FCC Chairman Reed Hundt, whose Commission decides whether to renew the broadcasters' licenses. Chairman Hundt, focusing specifically on talk radio, "urged station owners and management to ... emphasiz[e] accuracy and truth over a quest for ratings and

146. 723 F. Supp. 1347 (W.D. Mo. 1989).

147. See supra part II.B.2.

148. New York Times Co. v. Sullivan, 376 U.S. 254 (1964); see also id. at 279 n. 19 ("[E]ven a false statement may be deemed to make a valuable contribution to public debate."). 
advertising dollars." 49 "As a society," the chairman said, "we need solutions to public disinformation and misinformation, but solutions that don't involve governmental intrusion and yet don't leave us callously indifferent to truth or falsity." ${ }^{50}$ While this isn't yet a call for greater regulation-the chairman specifically "stressed that the FCC should not be the judge of content or quality in radio's public discourses"151 - it shows the sort of concern that may be a harbinger of future regulatory proposals.

Finally, current First Amendment law developed in a time when the public got its news and opinion from sources that provided a relatively broad mix of topics and viewpoints. Someone buying a newspaper or watching the nightly news would see a variety of stories, stories that professional editors thought fairly covered the most important issues facing the nation. And these stories would be a common base that people would be able to talk about with their acquaintances. The media, of course, were often criticized for falling down on the job, by covering fluff instead of the really important issues. ${ }^{152}$ But these criticisms only help show that people do think it's the media's job to give the public a trustworthy mix of the truly important news of the day.

As listeners get more control over the topics and viewpoints they see, ${ }^{153}$ they may choose to focus on a much narrower mix of information. They may subscribe only to articles on topics in which they're interested, or to commentators with whose opinions they already agree. They may consciously choose fluff-more easily than they can today-over serious news. ${ }^{154}$

Listeners will no longer be a captive audience to the selection that the intermediaries-publishers and broadcasters-want to feed them. Will listeners do a better job of informing themselves than the intermediaries have been doing? When the media aren't there to help set a national agenda, or to give people a common base of information to argue from, will people be able to deliberate together? I think the answer to both questions is yes, but others, including many in the audience when I presented this paper at the Symposium, disagree.

In my view, none of these changes, significant as they may be, should cause us to reconsider the basics of First Amendment law. The dangers of extremists with access to the media, of falsehoods with an audience in the millions, and of an ill-informed electorate are quite real; but the dangers of content regulation, it seems to me, are greater. And the dangers of regulation are exacerbated by the difficulty of doing anything about the most significant

149. Puig, supra note 99 at D2.

150. Id.

151. Id.

152. See, e.g., SUNSTEIN, supra note 1. at 59-62.

153. See supra part II.B.1.

154. See SUNSTEIN, supra note 1, at 20-21 (suggesting that people may foolishly underconsume important information about political affairs). 
problems (here, the possibility that people will choose to watch or read infotainment instead of the important news of the day seems particularly intractable). Finally, the criticisms by Dean Thomas G. Krattenmaker and Professor L.A. Powe of the FCC's attempts at content regulation seem to me hard to answer. ${ }^{\text {15s }}$

Still, the media will change, and change dramatically. As people find themselves in a new media environment there'll be new calls for regulation, and new calls for changes to First Amendment doctrines that some people may think are no longer apt.

I may be wrong in my predictions about what the new media order will look like. But the one thing that seems certain is that the new order will, in many ways, be vastly different from the old.

155. See generally KRATTENMAKER \& POWE, supra note 81; Thomas G. Krattenmaker \& L.A. Powe, Jr., Converging First Amendment Principles for Converging Communications Media, 104 YALE L.J. 1719 (1995). 



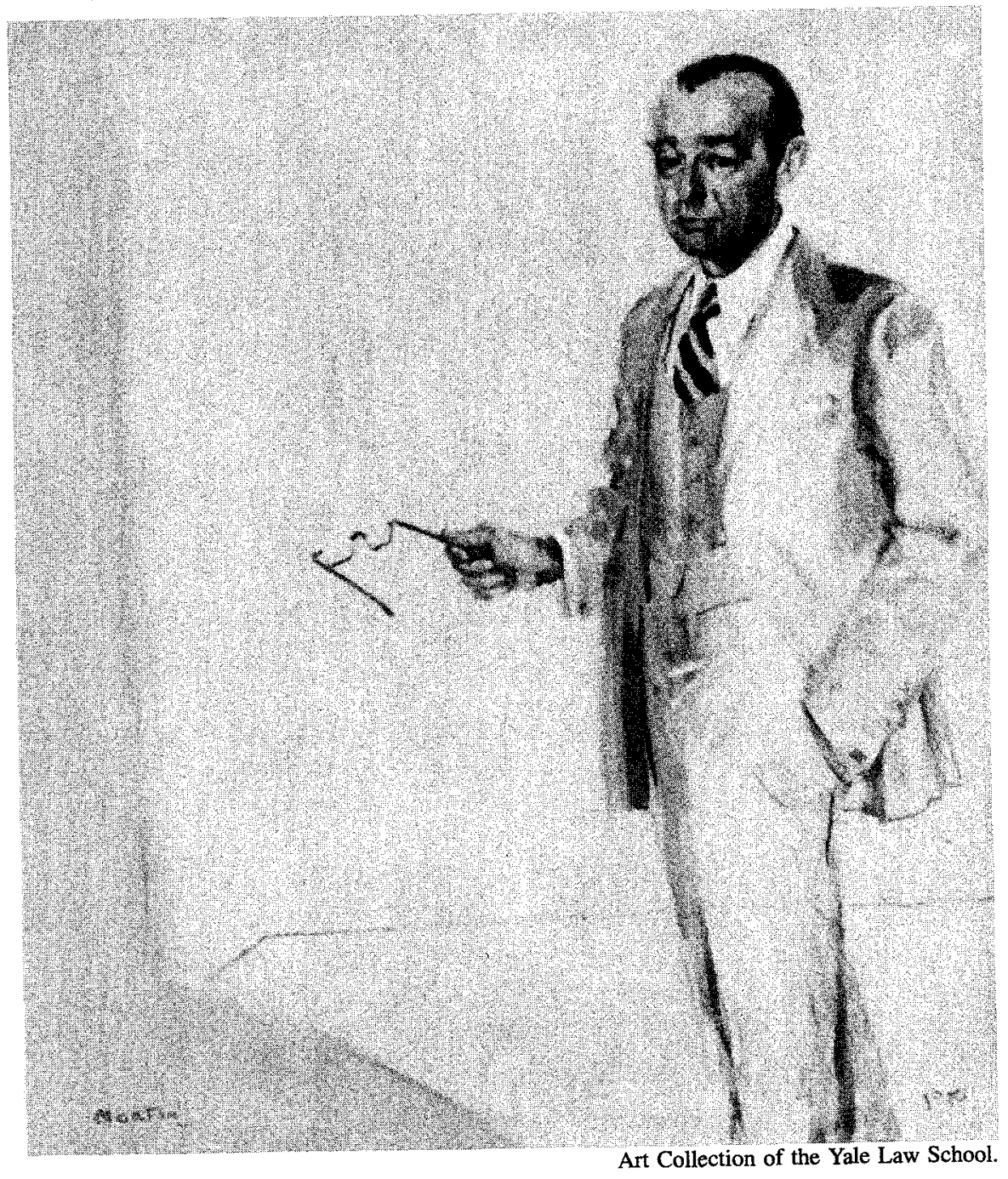

Alexander M. Bickel Portrait in

Room 127, Yale Law School 